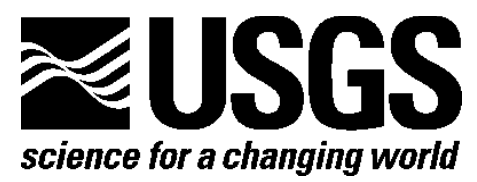

\title{
Global Surface Displacement Data for Assessing Variability of Displacement at a Point on a Fault
}

By Suzanne Hecker, Robert Sickler, Leah Feigelson, Norman Abrahamson, Will Hassett, Carla Rosa, and Anne Sanquini

Open-File Report 2013-1305 


\section{U.S. Department of the Interior \\ SALLY JEWELL, Secretary}

\section{U.S. Geological Survey \\ Suzette M. Kimball, Acting Director}

U.S. Geological Survey, Reston, Virginia: 2014

For more information on the USGS-the Federal source for science about the Earth,

its natural and living resources, natural hazards, and the environment-visit

http://www.usgs.gov or call 1-888-ASK-USGS

For an overview of USGS information products, including maps, imagery, and publications, visit $h$ ttp://www.usgs.gov/pubprod

To order this and other USGS information products, visit $h$ ttp://store.usgs.gov

Suggested citation:

Hecker, Suzanne, Sickler, Robert, Feigelson, Leah, Abrahamson, Norman, Hassett, Will, Rosa, Carla, and Sanquini, Anne, 2014, Global surface displacement data for assessing variability of displacement at a point on a fault: U.S. Geological Survey Open-File Report 2013-1305, 28 p., http://dx.doi.org/10.3133/ofr20131305.

ISSN 2331-1258 (online)

Any use of trade, firm, or product names is for descriptive purposes only and does not imply endorsement by the U.S. Government.

Although this information product, for the most part, is in the public domain, it also may contain copyrighted materials as noted in the text. Permission to reproduce copyrighted items must be secured from the copyright owner. 


\section{Contents}

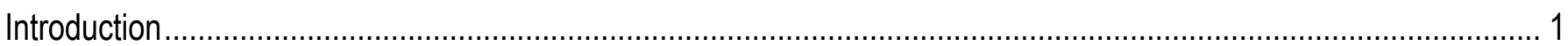

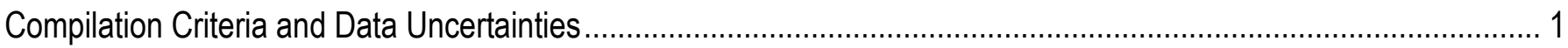

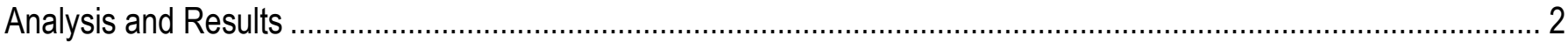

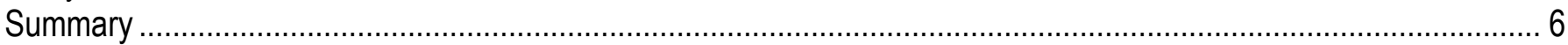

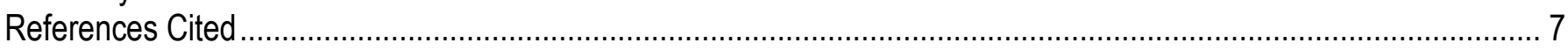

\section{Figures}

Figure 1. Graph showing distribution of sites by the number of events at a site ................................................ 3

Figure 2. Graph showing distribution of sites by fault style. ............................................................................... 4

\section{Tables}

Table 1. Global Compilation of Surface Displacement at a Point on a Fault

Table 2. Computed coefficient of variation (CV) and standard error of the estimate for subsets of data..... 6 
This page left intentionally blank 


\title{
Global Surface Displacement Data for Assessing Variability of Displacement at a Point on a Fault
}

\author{
By Suzanne Hecker, Robert Sickler, Leah Feigelson, Norman Abrahamson, Will Hassett, Carla Rosa, and Anne \\ Sanquini
}

\section{Introduction}

This report presents a global dataset of site-specific surface-displacement data on faults (table 1). We have compiled estimates of successive displacements attributed to individual earthquakes, mainly paleoearthquakes, at sites where two or more events have been documented, as a basis for analyzing inter-event variability in surface displacement on continental faults.

An earlier version of this composite dataset was used in a recent study relating the variability of surface displacement at a point to the magnitude-frequency distribution of earthquakes on faults, and to hazard from fault rupture (Hecker and others, 2013). The purpose of this follow-on report is to provide potential data users with an updated comprehensive dataset, largely complete through 2010 for studies in English-language publications, as well as in some unpublished reports and abstract volumes.

Table 1. Global Compilation of Surface Displacement at a Point on a Fault.

[Table 1 is a Microsoft ${ }^{\mathcal{O}}$ Excel file and can be downloaded at http://pubs.usgs.gov/of/2013/1305/.]

\section{Compilation Criteria and Data Uncertainties}

For this compilation effort, we have included no more than one study site per section of fault (for faults that have been segmented or otherwise subdivided), both to reduce the correlation of displacement values between sites, and to make our task more manageable. For sections of fault with more than one set of observations, we selected the dataset with the best quality and the most events. Where we had a choice, we minimized the influence of along-strike variability by minimizing the distance between observations. However, some types of data necessarily involve observations at more than one location, such as records of accruing lateral displacements along strike-slip faults.

Ideally, displacement estimates should represent the net or the main component of displacement across the entire zone of faulting at a site. However, studies of distributed faulting commonly include only part of the zone, and observations for many strike-slip and oblique-slip faults consist only of the local vertical component of displacement. For these cases, any intra-event variation in the distribution of displacement across strike, or in the ratio of horizontal to vertical displacement at the site, would contribute to the variability of the displacements sampled. Studies of faults that have blind ruptures but produce surface or near-surface fault-related fold scarps also are included in this compilation. 
Sources of uncertainty affecting observed displacement variability are further discussed in Hecker and others (2013). That article includes, as an electronic supplement, a checklist of issues that can affect the accuracy of displacement measurements, recognition of events, or overall utility of results. Hecker and others (2013) developed and used this list as a guide for evaluating the quality of the datasets in their compilation. For the larger, updated compilation, we have excluded a formal evaluation of data quality because of the difficulty in consistency applying a subjective rating scheme among a group of compilers with varied backgrounds.

\section{Analysis and Results}

We have compiled 860 surface-displacement observations from 292 sites on faults in 34 countries (table 1). For almost one-half of these countries, the earliest studies date from 2000 or later, probably reflecting the global expansion of paleoseismology. Slightly more than one-half of the sampled faults are in the United States; one-third of the United States faults are in California.

The number of observations per site averages about three, although about 50 percent of the sites have only two documented displacements, and only 12 percent have more than four (fig. 1). This data distribution is essentially unchanged from the data distribution presented in Hecker and others (2013) for an earlier version of the compilation that contains 505 observations from 171 sites, primarily from studies available prior to 2000. The limited number of observations per site probably reflects a persistent difficulty worldwide in obtaining long records of paleoseismic displacements on individual faults. Organizing the data by style of faulting (fig. 2) shows that 50 percent of the sites are from normal or normal-oblique faults, 33 percent are from faults with dominantly strike-slip movement, and about 17 percent are from faults with a reverse sense of slip. 


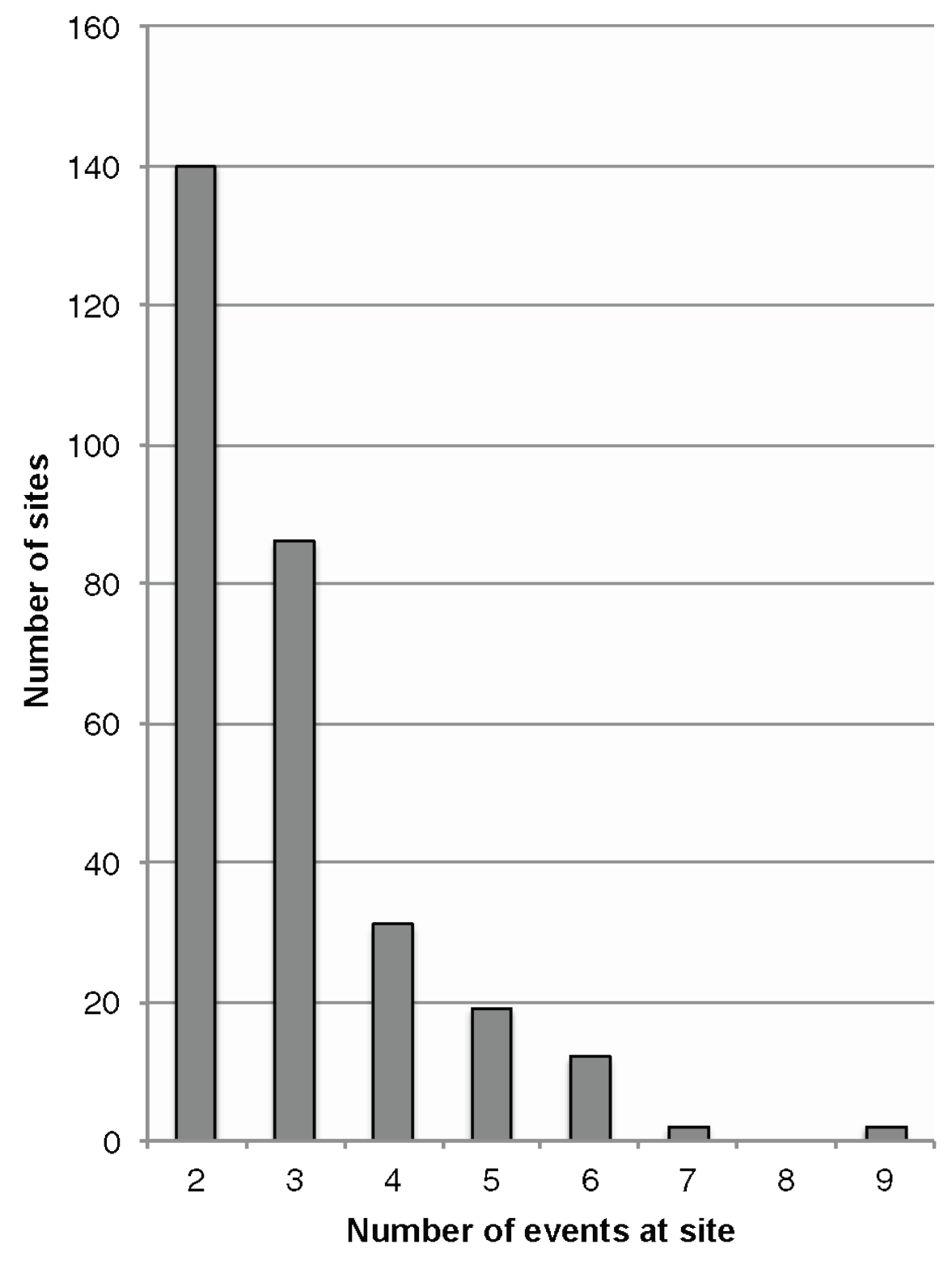

Figure 1. Graph showing distribution of sites by the number of events at a site. 


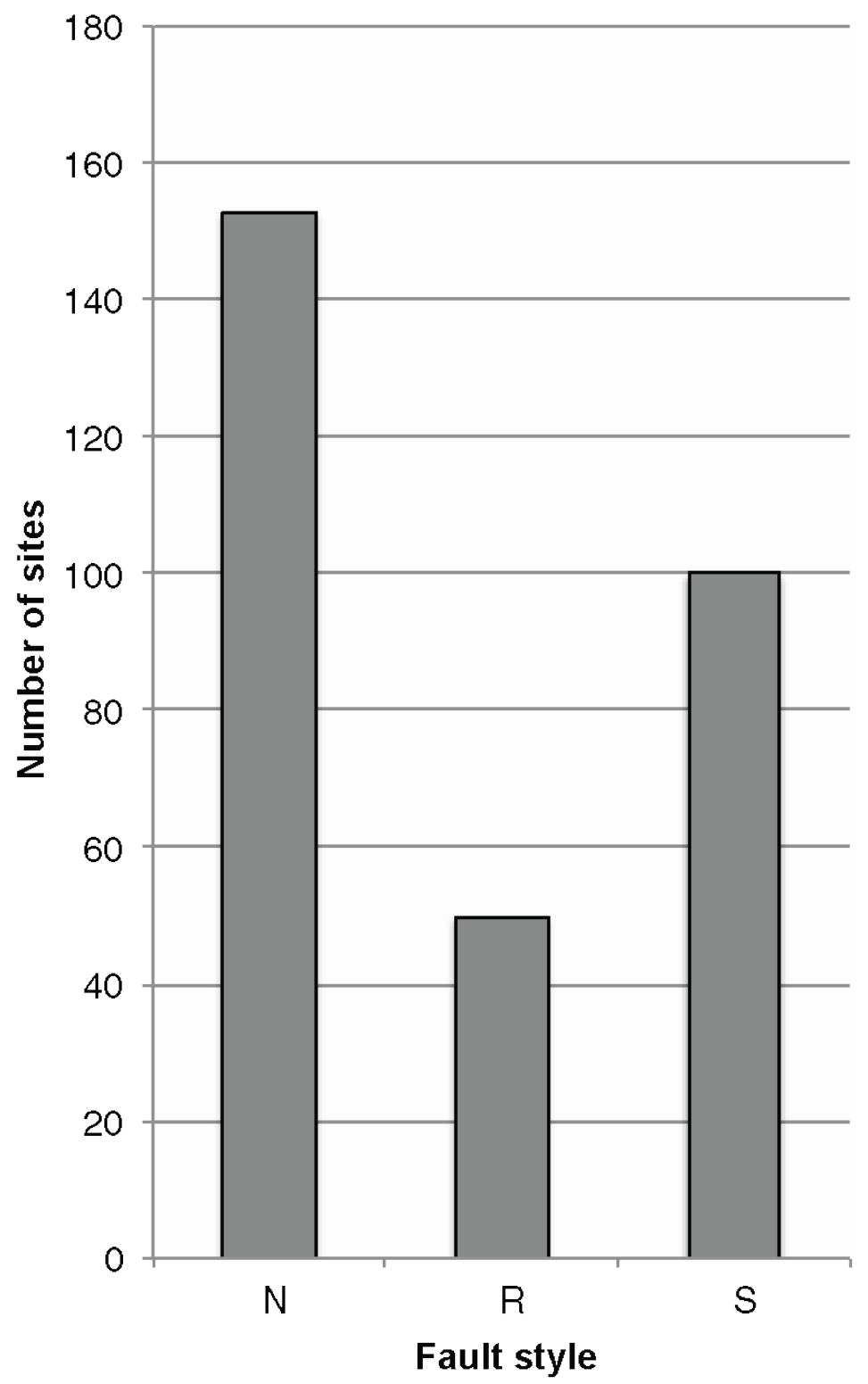

Figure 2. Graph showing distribution of sites by fault style. Eleven sites on oblique-slip faults having subequal components of horizontal and vertical slip are double-counted. $N=$ normal slip; $R=$ Reverse slip; $S=$ strike slip. 
To analyze inter-event variability in surface displacement at a point on a fault, Hecker and others (2013) created a composite dataset by normalizing the displacement values by the mean displacement at each site. Combining data from different sites requires making the assumption that the coefficient of variation $(\mathrm{CV})$ of the displacement, given by the ratio of the standard deviation to the mean, is constant for observations at all sites, or for a selected subset of sites. Then,

$$
C V=\sqrt{\frac{\sum_{i=1}^{N_{\text {Step }}} \sum_{j=1}^{N_{i}}\left(\frac{D_{i j}-\bar{D}_{i}}{\bar{D}_{i}}\right)^{2}}{\left(N_{\text {displ }}-N_{\text {site }}\right)},}
$$

in which $\mathrm{D}_{i j}$ is the $j^{\text {th }}$ displacement at site $i, N_{i}$ is the number of displacements for the $i$ th site, $N_{\text {site }}$ is the number of sites, and $N_{d i s p l}$ is the total number of displacements observed at all sites. The accuracy of the computed $\mathrm{CV}$ is characterized by the standard error (SE) of the estimate and is approximated by

$$
S E[C V]=\sqrt{\frac{1}{2\left(N_{\text {disgol }}-N_{\text {stte }}\right)}} C V \text {. }
$$

There are two main sampling issues that may bias the $\mathrm{CV}$ of our dataset: the small number of observations per site and the presence of events smaller than the limit of detectable displacement in the geologic record. Although addressing these issues is beyond the scope of this report, Hecker and others (2013) used a forward modeling approach to formally consider how factors such as these may affect the observed CV.

Using equations (1) and (2), we have estimated the CV for the data presented in Table 1, for the entire dataset and for subsets of the data based on faulting style. Following the procedure outlined in Hecker and others (2013), we compute the CV both with and without the uncertainty of the measured displacement (table 2). Some displacements include stated measurement error or interpretive uncertainty (recorded as minimum and maximum values in table 1); for displacements that did not include stated measurement error or interpretive uncertainty, we estimated the uncertainty of the observed displacement using a maximum-to-minimum displacement ratio of 1.5 , as determined from the subset of values with reported uncertainty in Hecker and others (2013).

Including the uncertainty of the measured displacement leads to a small increase in the estimated $\mathrm{CV}$ (table 2); in the following, we refer to the CV values that account for this uncertainty. Considering the standard error of the estimates, the $\mathrm{CV}$ of data grouped by sense of fault slip does not vary significantly (table 2 ). For the entire dataset, we compute a CV of $0.53 \pm 0.02$. This value is the same as that computed from the smaller dataset (171 sites; $C V=0.53 \pm 0.03$ ) used in Hecker and others (2013), indicating that this degree of variability is a stable feature of paleoseismic observations. 
Table 2. Computed coefficient of variation (CV) and standard error of the estimate for subsets of data.

[CV (w/o unc): Uses preferred values of displacement from table 1. For displacements reported as a range, mid-point is used as preferred displacement; for displacements reported as a minimum or maximum value, a scale factor of 1.25 is used to derive the preferred displacement (after Hecker and others, 2013). CV (w/unc): Incorporates range of uncertainty in estimates (minimum and maximum values, table 1). For estimates without stated uncertainty, a scale factor of 1.25 is applied to the preferred value to derive a range. Abbreviations: Unc, uncertainty in the measured displacement values; w/, with; w/o, without]

\begin{tabular}{lcccc}
\hline \multicolumn{1}{c}{ Dataset } & N site & N displ & CV (w/o unc) & CV (w/ unc) \\
\hline All data & 292 & 860 & $0.46 \pm 0.01$ & $0.53 \pm 0.02$ \\
Strike slip $^{1}$ & 100 & 285 & $0.44 \pm 0.02$ & $0.51 \pm 0.03$ \\
Normal slip $^{1}$ & 153 & 461 & $0.48 \pm 0.02$ & $0.54 \pm 0.03$ \\
Reverse slip $^{1}$ & 50 & 132 & $0.41 \pm 0.03$ & $0.51 \pm 0.04$
\end{tabular}

\footnotetext{
${ }^{\mathrm{I}}$ A total of 11 sites on oblique-slip faults having subequal components of lateral and vertical slip are double counted for this analysis.
}

\section{Summary}

In this report, we present a global compilation of earthquake surface-displacement data at sites where two or more events have been documented, as a basis for analyzing the intra-event variability in surface displacement at a point on crustal faults. The dataset, representing studies available through 2010, comprises 860 surface-displacement observations from 292 sites. About 50 percent of the sites have only two documented displacements, reflecting the difficulty in recovering long paleoseismic displacement records.

To analyze inter-event variability in displacement at a point, we construct a composite dataset by normalizing the observed displacement values by the mean displacement at each site (effectively substituting space for time), and compute the coefficient of variation (CV), given by the ratio of the standard deviation to the mean. For the entire dataset (and including uncertainty in the measured displacement values), we compute a $\mathrm{CV}$ of $0.53 \pm 0.02$. This value is essentially identical to the $\mathrm{CV}$ computed from an earlier version of the dataset for a study relating the variability of surface displacement at a point to the magnitude-frequency distribution of earthquakes and to hazard from fault rupture. 


\section{References Cited}

Allen, C.R., Luo, Z., Qian, H., Wen, X., Zhou, H., and Huang, W., 1991, Field study of a highly active fault zone-The Xianshuihe fault of southwestern China: Geological Society of America Bulletin, v. 103, p. 1,178-1,199.

Amit, R., Zilberman, E., Enzel, Y., and Porat, N., 2002, Paleoseismic evidence for time dependency of seismic response on a fault system in the southern Arava Valley, Dead Sea rift, Israel: Geological Society of America Bulletin, v. 114, no. 2, p. 192-206.

Amit, R., Zilberman, E., Porat, N., and Enzel, Y., 1999, Relief inversion in the Avrona Playa as evidence of large-magnitude historical earthquakes, Southern Arava Valley, Dead Sea Rift: Quaternary Research, v. 52, no. 1, p. 76-91.

Amoroso, L., Pearthree, P.A., and Arrowsmith, J.R., 2004, Paleoseismology and neotectonics of the Shivwits section of the Hurricane Fault, northwestern Arizona: Bulletin of the Seismological Society of America, v. 94, no. 5, p. 1,919-1,942.

Anderson, L.W., and Klinger, R.E., 2004, Quaternary faulting on the Bare Mountain Fault, chap. 12, in Keefer, W.R., Whitney, R.A., and Taylor, E.M., eds., Quaternary paleoseismology and stratigraphy of the Yucca Mountain Area, Nevada: U.S. Geological Survey Professional Paper 1689, p. 155-174, http://pubs.usgs.gov/pp/pp1689/.

Anderson, R.E., Crone, A.J., Machette, M.N., Bradley, L.A., and Diehl, S.F., 1995, Characterization of Quaternary and suspected Quaternary faults, Amargosa area, Nevada and California: U.S. Geological Survey Open-File Report 95-613, 41 p., http://pubs.er.usgs.gov/publication/ofr95613.

Asquith, D.O., 1985, Characteristics and alternative mechanisms of late Quaternary faulting, proposed LNG Terminal site, Point Conception, California: Bulletin of the Association of Engineering Geologists, v. 22, no. 2, p. 171-192.

Audemard, F.A., 1996, Paleoseismicity studies on the Oca-Ancon fault system, northwestern Venezuela: Tectonophysics, v. 259, p. 67-80.

Audemard, F.A., 1997, Holocene and historical earthquakes on the Bocono fault system, southern Venezuelan Andes-Trench confirmation: Journal of Geodynamics, v. 24, no. 1-4, p. 155-167.

Avouac, J.P., Liu, Qing, Tapponnier, P., and Bourjot, L., 1992, Quantitative estimates of Holocene and seismic movement along the Altyn Tagh and Longmu Co-Gozha Co faults (NW Tibet) [abs.], in Abstracts: Kashi, China, International Symposium on the Karakorum and Kunlun Mountains, p. 88.

Awata, Y., Sangawa, A., and Sugiyama, Y., 1998, [no title given] [abs.]: Eos, Transactions American Geophysical Union, v. 79, no. 45, p. F615.

Bachmanov, D.M., Trifonov, V.G., Hessami, K.T., Kozhurin, A.I., Ivanova, T.P., Rogozhin, E.A., Hademi, M.C., and Jamali, F.H., 2004, Active faults in the Zagros and central Iran: Tectonophysics, v. 380, p. 221-241.

Baljinnyam, I., Bayasgalan, A., Borisov, B.A., Cisternas, A., Dem'yanovich, M.G., Ganbattar, L., Kochetkov, V.M., Kurushin, R.A., Molnar, P., Philip, H., and Vashchilov, Y.Y., 1993, Ruptures of major earthquakes and active deformation in Mongolia and its surroundings: Geological Society of America Memoirs, v. 181, 59 p.

Baltzer, E.M., 1990, Quaternary surface displacements and segmentation of the northern Lemhi fault, Idaho: State University of New York at Binghamton, Master's thesis, $88 \mathrm{p.}$

Barnes, P.M., and Pondard, N., 2010, Derivation of direct on-fault submarine paleoearthquake records from high-resolution seismic reflection profiles-Wairau Fault, New Zealand: Geochemistry, Geophysics, Geosystems, v. 11, no. 11, Q11013, 22 p., doi:10.1029/2010gc003254. 
Barrell, D.J.A., Van Dissen, R.J., Berryman, K.R., and Read, S.A.L., 2005, Late Quaternary displacements on the Waitangi Fault, Aviemore Dam, South Island, New Zealand [abs.], in Pettinga, J.R., ed., 50th annual conference of the Geological Society of New Zealand: Geological Society of New Zealand Miscellaneous Publication, v. 119A, p. 5.

Barron, A.D., 2007, Paleoseismology of the Osgood Mountains, northern Basin and Range, Nevada: Reno, University of Nevada, Master's thesis, $60 \mathrm{p}$.

Bartholomew, M.J., 1989, The Red Rock fault and complexly deformed structures in the Tendoy and Four Eyes Canyon thrust sheets-Examples of late Cenozoic and late Mesozoic deformation in southwestern Montana, Road Log No. 2: Northwest Geology, v. 18, p. 21-35.

Beanland, S., and Barrow-Hurlbert, S.A., 1988, The Nevis-Cardrona fault system, Central Otago, New Zealand-Late Quaternary tectonics and structural development: New Zealand Journal of Geology and Geophysics, v. 31, no. 3, p. 337-352.

Beanland, S., Berryman, K.R., and Blick, G.H., 1989, Geological investigations of the 1987 Edgecumbe earthquake, New Zealand: New Zealand Journal of Geology and Geophysics, v. 32, p. 73-91.

Beanland, S., and Clark, M.M., 1994, The Owens Valley fault zone, eastern California, and surface faulting associated with the 1872 earthquake: U.S. Geological Survey Bulletin 1982, 29 p.

Bell, J.W., Caskey, S.J., Ramelli, A.R., and Guerrieri, L., 2004, Pattern and rates of faulting in the central Nevada seismic belt, and paleoseismic evidence for prior beltlike behavior: Bulletin of the Seismological Society of America, v. 94, no. 4, p. 1,229-1,254.

Bell, J.W., dePolo, C.M., Ramelli, A.R., Sarna-Wojcicki, A.M., and Meyer, C.E., 1999, Surface faulting and paleoseismic history of the 1932 Cedar Mountain earthquake area, west-central Nevada, and implications for modern tectonics of the Walker Lane: Geological Society of America Bulletin, v. 111, p. 791-807.

Bell, J.W., and Katzer, T., 1987, Surficial geology, hydrology, and late Quaternary tectonics of the IXL Canyon area, Nevada as related to the 1954 Dixie Valley earthquake: Nevada Bureau of Mines and Geology Bulletin, v. 102, 52 p.

Benedetti, L., Finkel, R., King, G., Armijo, R., Papanastassiou, D., Ryerson, F.J., Flerit, F., Farber, D., and Stavrakakis, G., 2003, Motion on the Kaparelli fault (Greece) prior to the 1981 earthquake sequence determined from ${ }^{36} \mathrm{Cl}$ cosmogenic dating: Terra Nova, v. 15, no. 2, p. 118-124.

Benedetti, L., Finkel, R., Papanastassiou, D., King, G., Armijo, R., Ryerson, F., Farber, D., and Flerit, F., 2002, Post-glacial slip history of the Sparta fault (Greece) determined by 36Cl cosmogenic dating -Evidence for non-periodic earthquakes: Geophysical Research Letters, v. 29, no. 8, p. 87-187-4, doi.10.1029/2001GL014510.

Berberian, M., Jackson, J.A., Fielding, E., Parsons, B.E., Priestley, K., Qorashi, M., Talebian, M., Walker, R., Wright, T.J., and Baker, C., 2001, The 1998 March 14 Fandoqa earthquake (M (sub w) 6.6) in Kerman Province, southeast Iran Re-rupture of the 1981 Sirch earthquake fault, triggering of slip on adjacent thrusts and the active tectonics of the Gowk fault zone: Geophysical Journal International, v. 146, no. 2, p. 371-398.

Berberian, M., Jackson, J.A., Qorashi, M., Khatib, M.M., Priestley, K., Talebian, M., and Ghafuri Ashtiani, M., 1999, The 1997 May 10 Zirkuh (Qa'enat) earthquake (Mw 7.2) Faulting along the Sistan suture zone of eastern Iran: Geophysical Journal International, v. 136, no. 3, p. 671-694.

Berryman, K., Beanland, S., and Wesnousky, S., 1998, Paleoseismicity of the Rotoitipakau Fault Zone, a complex normal fault in the Taupo Volcanic Zone, New Zealand: New Zealand Journal of Geology and Geophysics, v. 41, p. 449-465. 
Berryman, K.R., Beanland, S., Cooper, A.F., Cutten, H.N., Norris, R.J., and Wood, P.R., 1992, The Alpine fault, New Zealand Variation in Quaternary structural style and geomorphic expression: Annales Tectonicae-Special Issue VI, Supplement, p. 126-163.

Berryman, K.R., Villamor, P., Nairn, I.A., Van Dissen, R.J., Begg, J.G., and Lee, J.M., 2008, Late Pleistocene surface rupture history of the Paeroa Fault, Taupo Rift, New Zealand: New Zealand Journal of Geology and Geophysics, v. 51, no. 2, p. 135-158.

Bles, J.L., Ghafiri, A., Sebrier, M., Sauret, B., Terrier, M., Godefroy, P., and Martin, C., 1995, Neotectonics and palaeoseismicity in Provence (France) - Contributions to the evaluation of seismic hazard, in Cluff, L., and Pecker, A., co-chairmen, Proceedings of the Fifth International Conference on Seismic Zonation-October 17-18-19, 1995, Nice, France: Association francaise du genie parasismique and Earthquake Engineering Research Institute, Ouest Editions, Presses Academiques, p. 1,461-1,472.

Boccaletti, M., Caputo, R., Mountrakis, D., Pavlides, S., and Zouros, N., 1997, Paleoseismicity of the Souli Fault, Epirus, western Greece: Journal of Geodynamics, v. 24, no. 1-4, p. 117-127.

Brown, L.G., 1978, Recent fault scarps along the eastern escarpment of the Sierra San Pedro Martir, Baja, California: San Diego, Calif., San Diego State University, Master's thesis, 108 p.

Bull, W.B., and Pearthree, P.A., 1988, Frequency and size of Quaternary surface ruptures of the Pitaycachi fault, northeastern Sonora, Mexico: Bulletin of the Seismological Society of America, v. 78, no. 2, p. 956-978.

Byrd, J.O.D., 1991, Paleoseismicity of the southern section of the Teton normal fault, Wyoming [abs.]: Geological Society of America Abstracts with Programs, v. 23, no. 5, p. A481.

Byrd, J.O.D., 1995, Neotectonics of the Teton fault, Wyoming: Salt Lake City, University of Utah, Ph.D dissertation, $214 \mathrm{p}$.

Canora-Catalan, C., Villamor, P., Berryman, K., Martinez-Diaz, J.J., and Raen, T., 2008, Rupture history of the Whirinaki Fault, an active normal fault in the Taupo Rift, New Zealand: New Zealand Journal of Geology and Geophysics, v. 51, no. 4, p. 277-293.

Caputo, R., 1993, Morphotectonics and kinematics along the Tirnavos Fault, northern Larissa Plain, mainland Greece: Zeitschrift fur Geomorphologie, v. 94, p. 167-185.

Carver, G.A., and Burke, R.M., 1988, Trenching investigations of northwestern California faults, Humboldt Bay region: Final technical report to U.S. Geological Survey under contract 14-08-0001G1082, 53 p.

Carver, G.A., and McCalpin, J.P., 1996, Paleoseismology of compressional tectonic environments, chap. 5, in McCalpin, J.P., ed., Paleoseismology: San Diego, Calif., Academic Press, p. 183-270.

Caskey, S.J., Bell, J.W., Ramelli, A.R., and Wesnousky, S.G., 2004, Historic surface faulting and paleoseismicity in the area of the 1954 Rainbow Mountain-Stillwater earthquake sequence, central Nevada: Bulletin of the Seismological Society of America, v. 94, no. 4, p. 1,255-1,275.

Caskey, S.J., Wesnousky, S.G., Zhang, P., and Slemmons, D.B., 1996, Surface faulting of the 1954 Fairview Peak (Ms 7.2) and Dixie Valley (Ms 6.8) earthquakes, central Nevada: Bulletin of the Seismological Society of America, v. 86, no. 3, p. 761-787.

Chardon, D., Hermitte, D., Nguyen, F., and Bellier, O., 2005, First paleoseismological constraints on the strongest earthquake in France (Provence) in the twentieth century: Geology, v. 33, no. 11, p. 901904.

Chatzipetros, A., Kokkalas, S., Pavlides, S., and Koukouvelas, I., 2005, Palaeoseismic data and their implication for active deformation in Greece: Journal of Geodynamics, v. 40, p. 170-188. 
Chatzipetros, A., Pavlides, S., and Mourouzidou, O., 2004, Re-evaluation of Holocene earthquake activity in Mygdonia basin, Greece, based on new paleoseismological results, in Proceedings of 5th International Symposium on Eastern Mediterranean Geology, Thessaloniki, Greece, p. 920-923.

Chatzipetros, A., Pavlides, S.B., and Mountrakis, D.M., 1998, Understanding the 13 May 1995 western Macedonia earthquake-A paleoseismological approach: Journal of Geodynamics, v. 26, no. 2-4, p. 327-339.

Chen, W.-S., Lee, K.-J., Lee, L.-S., Streig, A.R., Rubin, C.M., Chen, Y.-G., Yang, H.-C., Chang, H.-C., and Lin, C.-W., 2007, Paleoseismic evidence for coseismic growth-fold in the 1999 Chichi earthquake and earlier earthquakes, central Taiwan: Journal of Asian Earth Sciences, v. 31, no. 3, p. 204-213.

Chen, W.-S., Yang, C.-C., Yen, I.C., Lee, L.-S., Lee, K.-J., Yang, H.-C., Chang, H.-C., Ota, Y., Lin, C.W., Lin, W.-H., Shih, T.-S., and Lu, S.-T., 2007, Late Holocene paleoseismicity of the southern part of the Chelungpu fault in central Taiwan-Evidence from the Chushan excavation site: Bulletin of the Seismological Society of America, v. 97, no. 1B, p. 1-13.

Cinti, F.R., Cucci, L., Pantosti, D., D'Addezio, G., and Meghraoui, M., 1997, A major seismogenic fault in a 'silent area'-The Castrovillari fault (southern Apennines, Italy): Geophysical Journal International, v. 130, no. 3, p. 595-605.

Clahan, K.B., 1996, Paleoseismic characteristics of the San Andreas Fault, Woodside, California: San Jose, Calif., San Jose State University, Master's thesis, 96 p.

Clark, D., Dentith, M., Wyrwoll, K.H., Yanchou, L., Dent, V., and Featherstone, W., 2008, The Hyden fault scarp, western Australia-Paleoseismic evidence for repeated Quaternary displacement in an intracratonic setting: Australian Journal of Earth Sciences, v. 55, no. 3, p. 379-395.

Clarke, S.H., Jr., and Carver, G.A., 1992, Late Holocene tectonics and paleoseismicity, southern Cascadia subduction zone: Science, v. 255, p. 188-192.

Coe, J.A., 2004, Quaternary faulting on the Northern Crater Flat Fault, chap. 11, in Keefer, W.R., Whitney, R.A., and Taylor, E.M., eds., Quaternary paleoseismology and stratigraphy of the Yucca Mountain Area, Nevada: U.S. Geological Survey Professional Paper 1689, p. 144-154, http://pubs.usgs.gov/pp/pp1689/.

Coe, J.A., Oswald, J., Vadurro, G., and Lunstrom, S.C., 2004, Quaternary faulting on the fatigue wash fault, chap. 8, in Keefer, W.R., Whitney, R.A., and Taylor, E.M., eds., Quaternary Paleoseismology and Stratigraphy of the Yucca Mountain Area, Nevada: U.S. Geological Survey Professional Paper 1689, p. 111-124, http://pubs.usgs.gov/pp/pp1689/.

Coe, J.A., Yount, J.C., O'Leary, D.W., and Taylor, E.M., 2004, Paleoseismic investigations on the Rock Valley fault system, chap. 13, in Keefer, W.R., Whitney, R.A., and Taylor, E.M., eds., Quaternary paleoseismology and stratigraphy of the Yucca Mountain Area, Nevada: U.S. Geological Survey Professional Paper 1689, p. 175-195, http://pubs.usgs.gov/pp/pp1689/.

Collier, R.E.L., Pantosti, D., D'Addezio, G., De Martini, P.M., Masana, E., and Sakellariou, D., 1998, Paleoseismicity of the 1981 Corinth earthquake fault - Seismic contribution to extensional strain in central Greece and implications for seismic hazard: Journal of Geophysical Research, v. 103, no. B12, p. 30,001-30,019.

Collins, E.W., and Raney, J.A., 1990, Neotectonic history and structural style of the Campo Grande fault, Hueco Basin, Trans-Pecos Texas: [Texas] Bureau of Economic Geology Report of Investigations 196, $39 \mathrm{p}$.

Collins, E.W., 1991, Tertiary and Quaternary structure and paleotectonics of the Hueco Basin, TransPecos Texas and Chihuahua, Mexico: [Texas] Bureau of Economic Geology Geological Circular 91$2,44 \mathrm{p}$. 
Collins, E.W., 1997, Quaternary faults within Intermontane basins of northwest Trans-Pecos Texas and Chihuahua, Mexico: [Texas] Bureau of Economic Geology Report of investigations No. 245, 49 p.

Crone, A.J., Machette, M.N., and Bowman, J.R., 1997, Episodic nature of earthquake activity in stable continental regions revealed by palaeoseismicity studies of Australian and North American Quaternary faults: Australian Journal of Earth Sciences, v. 44, no. 2, p. 203-214.

Cutten, H.N.C., Beanland, S., and Berryman, K.R., 1988, The Rangiora fault, an active structure in Hawkes Bay: New Zealand Geological Survey Record, v. 35, p. 65-72.

D'Addezio, G., Masana, E., and Pantosti, D., 2001, The Holocene paleoseismicity of the AremognaCinque Miglia Fault (central Italy): Journal of Seismology, v. 5, no. 2, p. 181-205.

de Lange, P.J., and Lowe, D.J., 1990, History of vertical displacement of Kerepehi Fault at Kopouatai bog, Hauraki Lowlands, New Zealand, since c. 10,700 years ago: New Zealand Journal of Geology and Geophysics, v. 33, no. 2, p. 277-283.

Deng, Q., and Liao, Y., 1996, Paleoseismology along the range-front fault of Helan Mountains, northcentral China: Journal of Geophysical Research, v. 101, no. B3, p. 5,873-5,893.

Deng, Q., Zhang, P., Xu, X., Yang, X., and Peng, S., 1996, Paleoseismology of the northern piedmont of Tianshan: Journal of Geophysical Research, v. 101, p. 5,895-5,920.

dePolo, C.M., Bell, J.W., Boron, S., Slemmons, D.B., and Werle, J.L., 2006, Latest Quaternary fault movement along the Las Vegas Valley fault system, Clark County, Nevada: Environmental \& Engineering Geoscience, v. 12, no. 2, p. 181-193.

dePolo, C.M., and Ramelli, A.R., 2004, Paleoseismic studies along the Warm Springs Valley fault system: Final Technical Report to U.S. Geological Survey under contract 01HQGR0119, 41 p. dePolo, C.M., and Sawyer, T.L., 2005, Paleoseismic studies along the Eastern Carson Valley fault system: Final Technical Report to U.S. Geological Survey under contract 03HQGR0090, 33 p.

Ding, G., 1996, Paleoseismicity and rupture segments along the Altun Fault in the past 22 ka: Seismology and Geology, v. 18, Supplement, p. 38-48.

Dolan, J.F., 2010, Paleoseismology and seismic hazards of the San Cayetano fault zone: Final Technical Report to U.S. Geological Survey under contract 02HQGR0041, 21 p.

DuRoss, C.B., Crone, A.J., Hylland, M.D., McDonald, G.N., Personius, S.F., Gold, R.D., and King, B.D., 2010, Multiple Holocene surface-rupturing earthquakes on the East Bench fault, Salt Lake City, Utah [abs.]: Geological Society of America Abstracts with Programs, v. 42, no. 5, p. 595.

DuRoss, C.B., Personious, S.F., Crone, A.J., McDonald, G.N., and Lidke, D.J., 2009, Paleoseismic investigation of the northern Weber segment of the Wasatch fault zone at the Rice Creek trench site, North Ogden, Utah: Paleoseismology of Utah, v. 18 [Utah Geological Survey Special Study 130], 37 p.

Ellenblum, R., Marco, S., Agnon, A., Rockwell, T., and Boas, A., 1998, Crusader castle torn apart by earthquake at dawn, 20 May 1202: Geology, v. 26, no. 4, p. 303-306.

Fenton, C.H., Charusiri, P., and Wood, S.H., 2003, Recent paleoseismic investigations in Northern and Western Thailand: Annals of Geophysics, v. 46, no. 5, p. 957-981.

Ferry, M., Meghraoui, M., Delouis, B., and Giardini, D., 2005, Evidence for Holocene palaeoseismicity along the Basel-Reinach active normal fault (Switzerland) - A seismic source for the 1356 earthquake in the Upper Rhine graben: Geophysical Journal International, v. 160, no. 2, p. 554-572.

Ferry, M., Meghraoui, M., Girard, J., Rockwell, T.K., Kozaci, O., Akyuz, S., and Barka, A., 2004, Ground-penetrating radar investigations along the North Anatolian fault near Izmit, TurkeyConstraints on the right-lateral movement and slip history: Geology, v. 32, no. 1, p. 85-88. 
Foley, L.L., LaForge, R.C., and Piety, L.A., 1988, Seismotectonic study for Elephant Butte and Caballo Dams, Rio Grande project, New Mexico: U.S. Bureau of Reclamation Seismotectonic Report 88-9, $60 \mathrm{p}$.

Foley, L.L., Martin, R.A., Jr., and Sullivan, J.T., 1986, Seismotectonic study for Joes Valley, Scofield and Huntington North Dams, Emery County and Scofield Projects, Utah: U.S. Bureau of Reclamation Seismotectonic Report 86-7, 132 p.

Fonseca, J.F., 1988, The Sou Hills - A barrier to faulting in the central Nevada seismic belt: Journal of Geophysical Research, v. 93, no. B1, p. 475-489.

Fraser, J.G., Nicol, A., Pettinga, J.R., and Johnston, M.R., 2006, Paleoearthquake investigation of the Waimea-Flaxmore fault system, Nelson, New Zealand, in New Zealand Geotechnical Society Symposium, Proceedings: Technical Groups, Institution of Professional Engineers New Zealand, v. 31, no. 1, p. 59-67.

Fumal, T.E., Davis, A.B., Frost, W.T., O'Donnell, J., Sega, G., and Schwartz, D.P., 1995, Recurrence studies of Tujunga segment of the 1971 San Fernando, California, earthquake [abs.]: Eos, Transactions American Geophysical Union, v. 76, no. 46, Supplement, p. 364.

Galadini, F., and Galli, P., 1999, The Holocene paleoearthquakes on the 1915 Avezzano earthquake faults (central Italy) - Implications for active tectonics in the central Apennines: Tectonophysics, $\mathrm{v}$. 308, no. 1-2, p. 143-170.

Galli, P., Bosi, V., Piscitelli, S., Giocoli, A., and Scionti, V., 2006, Late Holocene earthquakes in Southern Apennine-Paleoseismology of the Caggiano Fault: International Journal of Earth Sciences, v. 95, no. 5, p. 855-870.

Galli, P., Scionti, V., and Spina, V., 2007, New paleoseismic data from the Lakes and Serre faultsSeismotectonic implications for Calabria (southern Italy): Bollettino della Societa Geologica Italiana [Italian Journal of Geosciences], v. 126, no. 2, p. 347-364.

Galli, P.A.C., and Naso, J.A., 2009, Unmasking the 1349 earthquake source (southern Italy) Paleoseismological and archaeoseismological indications from the Aquae Iuliae fault: Journal of Structural Geology, v. 31, no. 2, p. 128-149.

Ganev, P.N., Dolan, J.F., Blisniuk, K., Oskin, M., and Owen, L.A., 2010, Paleoseismologic evidence for multiple Holocene earthquakes on the Calico fault-Implications for earthquake clustering in the eastern California shear zone: Lithosphere, v. 2, no. 4, p. 287-298.

Geomatrix Consultants, 1988a, Seismotectonic evaluation of the Wyoming Basin geomorphic province for Seminoe, Kortes, Pathfinder, Alcova and Gray Reef Dams: Unpublished report prepared for U.S. Bureau of Reclamation, Denver, Co., 167 p.

Geomatrix Consultants, 1988b, Seismotectonic evaluation of the northwestern Wind River Basin for Boysen, Bull Lake, Pilot Butte, Washakie, and Ray Lake Dams: Denver, Co., Unpublished report prepared for U.S. Bureau of Reclamation, $116 \mathrm{p}$.

Giaccio, B., Galadini, F., Sposato, A., Messina, P., Moro, M., Zreda, M., Cittadini, A., Salvi, S., and Todero, A., 2002, Image processing and roughness analysis of exposed bedrock fault planes as a tool for paleoseismological analysis - Results from the Campo Felice fault (central Apennines, Italy): Geomorphology, v. 49, no. 3-4, p. 281-301.

Giraudi, C., and Frezzotti, M., 1995, Palaeoseismicity in the Gran Sasso Massif (Abruzzo, central Italy): Quaternary International, v. 25, p. 81-93.

Gomez, F., Meghraoui, M., Darkal, A.N., Hijazi, F., Mouty, M., Suleiman, Y., Sbeinati, R., Darawcheh, R., Al-Ghazzi, R., and Barazangi, M., 2003, Holocene faulting and earthquake recurrence along the Serghaya branch of the Dead Sea fault system in Syria and Lebanon: Geophysical Journal International, v. 153, no. 3, p. 658-674. 
Hall, N.T., 1984, Late Quaternary history of the eastern Pleito thrust fault, northern transverse ranges, California: Palo Alto, Calif., Stanford University, Ph.D dissertation, 89 p.

Hall, N.T., Wright, R.H., and Clahan, K.B., 1995, Paleoseismic investigations of the San Andreas fault on the San Francisco Peninsula, California: Final Technical Report to U.S. Geological Survey under contract 14-08-0001-G2081, 45 p.

Haller, K.M., 1988, Segmentation of the Lemhi and Beaverhead faults, east-central Idaho, and Red Rock fault, southwestern Montana, during the late Quaternary: Boulder, University of Colorado, Master's thesis, $141 \mathrm{p}$.

Haller, K.M., Tsutsumi, H., Machette, M.N., Essex, J., and Hancock, D., 2000, Paleoseismology of the Grayling Creek site, Red Canyon fault (1959 Hebgen Lake, Montana, earthquake): Eos, Transactions American Geophysical Union, v. 81, no. 48, p. F1169-F1170.

Haller, K.M., 2002, Paleoseismic investigation of the 1959 Red Canyon fault, southwestern Montana [abs.]: Geological Society of America Abstracts with Programs, v. 34, no. 4, p. A-4.

Hecker, S., Abrahamson, N.A., and Wooddell, K.E., 2013, Variability of displacement at a pointImplications for earthquake-size distribution and rupture hazard on faults: Bulletin of the Seismological Society of America, v. 103, no. 2A, p. 651-674.

Hemphill-Haley, M.A., Knuepfer, P.L.K., Forman, S.L., and Smith, R.P., 1992, Paleoseismic investigations of the southern Lemhi fault, Idaho: Final Technical Report to the U.S. Department of Energy under contract DE- AC07-76ID01570, 105 p.

Hemphill-Haley, M.A., Sawyer, T.L., Knuepfer, P.L.K., Forman, S.L., and Wong, I.G., 1994, Late Quaternary paleoseismicity and segmentation along the southern Lemhi Fault, southeastern Idaho, in Prentice, C.S., Schwartz, D.P., and Yeats, R.S., eds., Proceedings of the Workshop on

Paleoseismology: U.S. Geological Survey Open-File Report 94-568, p. 81-83, http://pubs.er.usgs.gov/publication/ofr94568.

Hill, R.L., Treiman, J.A., and Given, J.W., 1980, Geologic study of the Homestead Valley earthquake swarm of March 15, 1979: California Geology, v. 88, p. 60-67.

Hitchcock, C., Altunel, E., Barka, A.A., Bachhuber, J., Lettis, W., Kozaci, O., Helms, J., and Lindvall, S., 2003, Timing of late Holocene earthquakes on the eastern Duzce Fault and implications for slip transfer between the southern and northern strands of the North Anatolian fault system, Bolu, Turkey: Turkish Journal of Earth Sciences, v. 12, no. 1, p. 119-136.

Hitchcock, C.S., Lindvall, S.C., Treiman, J.A., Weaver, K.D., Helms, J.G., and Lettis, W.R., 2001, Paleoseismic investigation of the Simi fault, Ventura County, California: Final Technical Report to U.S. Geological Survey under contract 99HQGR0094, 31 p.

Hudnut, K.W., Seeber, L., and Rockwell, T., 1989, Slip on the Elmore Ranch fault during the past 330 years and its relation to slip on the Superstition Hills fault: Bulletin of the Seismological Society of America, v. 79, no. 2, p. 330-341.

Hylland, M.D., 2007, Surficial-geologic reconnaissance and scarp profiling on the Collinston and Clarkston Mountain segments of the Wasatch fault zone, Box Elder County, Utah-Paleoseismic inferences, implications for adjacent segments, and issues for diffusion-equation scarp-age modeling: Paleoseismology of Utah, v. 15 [Utah Geological Survey Special Study 121], 18 p.

Ikeda, Y., Suzuki, Y., Herece, E., Saroglu, F., Isikara, A.M., and Honkura, Y., 1991, Geological evidence for the last two faulting events on the North Anatolian fault zone in the Mudurnu Valley, western Turkey: Tectonophysics, v. 193, no. 4, p. 335-345. 
Improta, L., Ferranti, L., De Martini, P.M., Piscitelli, S., Bruno, P.P., Burrato, P., Civico, R., Giocoli, A., Iorio, M., D'Addezio, G., and Maschio, L., 2010, Detecting young, slow-slipping active faults by geologic and multidisciplinary high-resolution geophysical investigations-A case study from the Apennine seismic belt, Italy: Journal of Geophysical Research, v. 115, B11307, 26 p., doi.10.1029/2010jb000871.

Ito, T., Uesugi, Y., Yonezawa, H., Kano, K., Someno, M., Chiba, T., and Kimura, T., 1987, Analytical method for evaluating superficial fault displacements in volcanic air fall deposits - Case of the Hirayama fault, south of Tanzawa Mountains, central Japan, since 21,500 years B.P.: Journal of Geophysical Research, v. 92, no. B10, p. 10,683-10,685.

Jiang, W., Hou, Z., and Xie, X., 2002, Research on paleoearthquakes in Jiuxian trenches across NankouSunhe fault zone in Changping County of Beijing plain-Science in China Series D: Earth Sciences, v. 45 , no. 2 , p. 160-173.

Johnson, S.Y., Nelson, A.R., Personius, S.F., Wells, R.E., Kelsey, H.M., Sherrod, B.L., Okumura, K., Koehler, R., Witter, R.C., Bradley, L.-A., and Harding, D.J., 2004, Evidence for late Holocene earthquakes on the Utsalady Point fault, northern Puget Lowland, Washington: Bulletin of the Seismological Society of America, v. 94, no. 6, p. 2,299-2,316.

Jones, L.C.A., 1995, The Quaternary geology of the eastern side of the Greys River Valley and the neotectonics of the Greys River fault in western Wyoming: Logan, Utah State University, Master's thesis, $116 \mathrm{p}$.

Kelsey, H.M., Hull, A.G., Cashman, S.M., Berryman, K.R., Cashman, P.H., Trexler, J.H., Jr., and Begg, J.G., 1998, Paleoseismology of an active reverse fault in a forearc setting-The Poukawa fault zone, Hikurangi forearc, New Zealand: Geological Society of America Bulletin, v. 110, no. 9, p. 1,1231,148 .

Kelson, K.I., Baldwin, J.N., and Randolph, C.E., 1998, Late Holocene slip rate and amounts of coseismic rupture along the central Calaveras fault, San Francisco Bay area, California: Final Technical Report to U.S. Geological Survey under contract 1434-HQ-97-GR-03151, 25 p.

Kelson, K.I., Bauer, P.W., Connell, S.D., Love, D.W., Rawling, G.C., and Mansell, M., 2004, Initial paleoseismic and hydrologic assessment of the southern Sangre de Cristo Fault at the Taos Pueblo site, Taos County, New Mexico, in Brister, B.S., Bauer, P.W., Read, A.S., and Lueth, V.W., eds., Geology of the Taos Region: New Mexico Geological Society Guidebook, 55th Field Conference, p. 289-299.

Klinger, R.E., and Piety, L.A., 1996, Evaluation and characterization of Quaternary faulting on the Death Valley and Furnace Creek faults, Death Valley, California: U.S. Bureau of Reclamation Seismotectonic Report 96-10, 98 p.

Klinger, R.E., and Piety, L.A., 2001, Holocene faulting and slip rates along the Black Mountains fault zone near Mormon Point, in Machette, M.N., Johnson, M.L., and Slate, J.L., eds., Quaternary and late Pliocene geology of the Death Valley region-Recent observations on tectonics, stratigraphy, and lake cycles: U.S. Geological Survey Open-File Report 01-51, p. L193-L203, http://pubs.er.usgs.gov/publication/ofr0151.

Klinger, Y., Avouac, J.P., Dorbath, L., Abou Karaki, N., and Tisnerat, N., 2000, Seismic behaviour of the Dead Sea Fault along Araba Valley, Jordan: Geophysical Journal International, v. 142, no. 3, p. 769-782.

Klinger, Y., Sieh, K., Altunel, E., Akoglu, A., Barka, A.A., Dawson, T.E., Gonzalez, T., Meltzner, A.J., and Rockwell, T.K., 2003, Paleoseismic evidence of characteristic slip on the western segment of the North Anatolian Fault, Turkey: Bulletin of the Seismological Society of America, v. 93, no. 6, p.

$2,317-2,332$. 
Knuepfer, P.L.K., Baltzer, E.M., and Turko, J.M., 1989, Repeatability of fault rupture segments and earthquake potential: Final Technical Report to U.S. Geological Survey under contract 14-08-0001G1527, 32 p.

Komatsubara, T., Mizuno, K., Sangawa, A., Nanayama, F., Kinoshita, H., Matsuki, H., Niimi, K., Mano, M., Yoshimura, T., Inoue, M., Kuzuhara, H., Zushi, T., Nakamura, Y., and Yokoigawa, H., 1999, Paleoseismological survey of the Aibano fault, northern part of the Biwako Seigan active fault system, Kinki District: Journal of the Seismological Society of Japan, 2nd series, v. 51, no. 4. [in Japanese with English summary], p. 379-394.

Komatsubara, T., Mizuno, K., Sangawa, A., Nanayama, F., Kinoshita, H., Matsuki, H., Niimi, K., Yoshimura, T., Inoue, M., Ikawa, N., Kuzuhara, H., Nakamura, Y., Zushi, T., and Yokoigawa, H., 1998, Late Quaternary activity of the Aibano fault, western side of Lake Biwa, Kinki District, Japan: Bulletin of the Geological Survey of Japan, v. 49, no. 9 [in Japanese with English summary], p. 447460.

Kondo, H., Kurcer, A., Ozalp, S., and Emre, O., 2010, Flexible slip history on the 1942 Erbaa-Niksar earthquake rupture along the North Anatolian fault system, Turkey [abs.]: Geophysical Research Abstracts, v. 12, EGU2010-3087.

Kondo, H., Nakata, T., Akhtar, S.S., Wesnousky, S.G., Sugito, N., Kaneda, H., Tsutsumi, H., Khan, A.M., Khattak, W., and Kausar, A.B., 2008, Long recurrence interval of faulting beyond the 2005 Kashmir earthquake around the northwestern margin of the Indo-Asian collision zone: Geology, v. 36, no. 9, p. 731-734.

Kondo, H., Ozaksoy, V., and Yildirim, C., 2010, Slip history of the 1944 Bolu-Gerede earthquake rupture along the North Anatolian fault system; implications for recurrence behavior of multisegment earthquakes: Journal of Geophysical Research, v. 115, B04316, 16 p., doi.10.1029/2009JB006413.

Kondo, H., Toda, S., Imaizumi, T., Tsutsumi, H., Sugishita, I., Nakata, T., Okumura, K., Shimazaki, K., Takada, K., Ikeda, T., and Haraguchi, T., 2003, Recent non-characteristic behavior along the Tanna fault based on three-dimensional trenching and geoslicer techniques: Journal of the Seismological Society of Japan, v. 55, no. 4 [in Japanese with English summary], p. 407-424.

Koning, D.J., 1999, Fault segmentation and paleoseismicity of the southern Alamogordo fault, southern Rio Grande rift, New Mexico: Albuquerque, University of New Mexico, Master's thesis, 286 p.

Koukouvelas, I.K., Stamatopoulos, L., Katsonopoulou, D., and Pavlides, S., 2001, A palaeoseismological and geoarchaeological investigation of the Eliki fault, Gulf of Corinth, Greece: Journal of Structural Geology, v. 23, no. 2-3, p. 531-543.

Kumar, S., Wesnousky, S.G., Rockwell, T.K., Briggs, R.W., Thakur, V.C., and Jayangondaperumal, R., 2006, Paleoseismic evidence of great surface rupture earthquakes along the Indian Himalaya: Journal of Geophysical Research, v. 111, B03304, 19 p., doi.10.1029/2004jb003309.

Kumar, S., Wesnousky, S.G., Rockwell, T.K., Ragona, D., Thakur, V.C., and Seitz, G.G., 2001, Earthquake recurrence and rupture dynamics of Himalayan frontal thrust, India: Science, v. 294, no. 5,550 , p. 2,328-2,331.

Kurushin, R.A., Bayasgalan, A., Olziybat, M., Enhtuvshin, B., Molnar, P., Bayarsayhan, C., Hudnut, K.W., and Lin, J., 1997, The surface rupture of the 1957 Gobi-Altay, Mongolia earthquake: Geological Society of America Special Paper 320, 143 p.

Langridge, R.M., and Berryman, K.R., 2005, Morphology and slip rates of the Hurunui section of the Hope Fault, South Island, New Zealand: New Zealand Journal of Geology and Geophysics, v. 48, no. 1, p. 43-57. 
Langridge, R.M., Weldon, R.J., Moya, J.C., and Suarez, G., 2000, Paleoseismology of the 1912 Acambay earthquake and the Acambay-Tixmadeje Fault-Trans-Mexican volcanic belt: Journal of Geophysical Research, v. 105, no. B2, p. 3,019-3,037.

Lasserre, C., Morel, P.-H., Gaudemer, Y., Tapponnier, P., Ryerson, F.J., King, G.C.P., Metivier, F., Kasser, M., Kashgarian, M., Liu, B., Lu, T., and Yuan, D., 1999, Postglacial left slip rate and past occurrence of $\mathrm{M} \geq 8$ earthquakes on the western Haiyuan fault, Gansu, China: Journal of Geophysical Research, v. 104, no. B8, p. 17,633-17,651.

Leon, L.A., Christofferson, S.A., Dolan, J.F., Shaw, J.H., Pratt, T.L., and Avouac, J.-P., 2007, Earthquake-by-earthquake fold growth above the Puente Hills blind thrust fault, Los Angeles, California-Implications for fold kinematics and seismic hazard: Journal of Geophysical Research, v. 112, B03S03, 18 p., doi.10.1029/2006JB004461.

Leon, L.A., Dolan, J.F., Shaw, J.H., and Pratt, T.L., 2009, Evidence for large Holocene earthquakes on the Compton thrust fault, Los Angeles, California: Journal of Geophysical Research, v. 114, B12305, 14 p., doi.10.1029/2008JB006129.

Leonard, M., Robinson, D., Allen, T., Schneider, J., Clark, D., Dhu, T., and Burbidge, D., 2007, Toward a better model of earthquake hazard in Australia, in Stein, S., and Mazzotti, S., eds., Continental intraplate earthquakes - Science, Hazard, and Policy Issues: Geological Society of America Special Paper 425, p. 263-283.

Li, H., van der Woerd, J., Tapponnier, P., Klinger, Y., Qi, X., Yang, J., and Zhu, Y., 2005, Slip rate on the Kunlun Fault at Hongshui Gou, and recurrence time of great events comparable to the 14/11/2001, Mw 7.9 Kokoxili earthquake: Earth and Planetary Science Letters, v. 237, no. 1-2, p. 285-299.

Lienkaemper, J.J., Baker, B., McFarland, F.S., Harris, R.A., and Arrowsmith, J.R., 2006, Surface slip associated with the 2004 Parkfield, California, earthquake measured on alinement arrays: Bulletin of the Seismological Society of America, v. 96, no. 4B, p. S239-S249.

Lin, A., Maruyama, T., and Miyata, T., 1998, Paleoseismic events and the 1596 Keicho-Fushimi large earthquake produced by a slip on the Gosukebashi fault at the eastern Rokko Mountains, Japan: Island Arc, v. 7, p. 621-636.

Lin, A., Ren, Z., Jia, D., and Miyairi, Y., 2010, Evidence for a Tang-Song Dynasty great earthquake along the Longmen Shan Thrust Belt prior to the $2008 \mathrm{Mw} 7.9$ Wenchuan earthquake, China: Journal of Seismology, v. 14, no. 3, p. 615-628.

Lindvall, S.C., Rockwell, T.K., and Hudnut, K.W., 1989, Evidence for prehistoric earthquakes on the Superstition Hills fault from offset geomorphic features: Bulletin of the Seismological Society of America, v. 79, no. 2, p. 342-361.

Little, T.A., Van Dissen, R., Rieser, U., Smith, E.G.C., and Langridge, R.M., 2010, Coseismic strike slip at a point during the last four earthquakes on the Wellington fault near Wellington, New Zealand: Journal of Geophysical Research, v. 115, B05403, 22 p., doi:10.1029/2009JB006589.

Liu, J., Klinger, Y., Sieh, K., and Rubin, C., 2004, Six similar sequential ruptures of the San Andreas fault, Carrizo Plain, California: Geology, v. 32, no. 8, p. 649-652.

Liu, J., Klinger, Y., Sieh, K., Rubin, C., and Seitz, G., 2006, Serial ruptures of the San Andreas fault, Carrizo Plain, California, revealed by three-dimensional excavations: Journal of Geophysical Research, v. 111, B02306, 33 p., doi:10.1029/2004JB003601.

Losh, S.L., Ostenaa, D.A., and Nelson, A.R., 1982, Recurrent late Quaternary faulting-Sawatch Fault, Colorado [abs.]: Eos, Transactions American Geophysical Union, v. 63, no. 18, p. 435.

Lubetkin, L.K.C., and Clark, M.M., 1988, Late Quaternary activity along the Lone Pine Fault, eastern California: Geological Society of America Bulletin, v. 100, no. 5, p. 755-766. 
Machette, M.N., 1987, Preliminary assessment of paleoseismicity at White Sands Missile Range, southern New Mexico-Evidence for recency of faulting, fault segmentation, and repeat intervals for major earthquakes in the region: U.S. Geological Survey Open-File Report 87-444, 46 p., http://pubs.er.usgs.gov/publication/ofr87444.

Machette, M.N., 1988, Quaternary movement along the La Jencia fault, central New Mexico: U.S. Geological Survey Professional Paper 1440, 82 p., http://pubs.er.usgs.gov/publication/pp1440.

Machette, M.N., Personius, S.F., and Nelson, A.R., 1992, Paleoseismology of the Wasatch fault zoneA summary of recent investigations, interpretations, and conclusions, in Gori, P.L., and Hays, W.W., eds., Assessment of regional earthquake hazards and risk along the Wasatch Front, Utah: U.S. Geological Survey Professional Paper 1500-A, p. A1-A71, http://pubs.er.usgs.gov/publication/pp1500KR.

Madden, C.L., Rubin, C.M., and Streig, A., 2006, Holocene and latest Pleistocene activity on the Mesquite Lake fault near Twentynine Palms, eastern California shear zone-Implications for fault interaction: Bulletin of the Seismological Society of America, v. 96, no. 4A, p. 1,305-1,320.

Malik, J.N., and Mathew, G., 2005, Evidence of paleoearthquakes from trench investigations across Pinjore Garden fault in Pinjore Dun, NW Himalaya: Journal of Earth System Science, v. 114, no. 4, p. 387-400.

Mann, G.M., and Meyer, C.E., 1993, Late Cenozoic structure and correlations to seismicity along the Olympic-Wallowa lineament, northwest United States: Geological Society of America Bulletin, v. 105, no. 7, p. 853-871.

Maruyama, T., Iemura, K., Azuma, T., Yoshioka, T., Sato, M., and Miyawaki, R., 2007, Paleoseismological evidence for non-characteristic behavior of surface rupture associated with the 2004 Mid-Niigata Prefecture earthquake, central Japan: Tectonophysics, v. 429, no. 1-2, p. 45-60.

Masana, E., Martínez-Díaz, J.J., Hernández-Enrile, J.L., and Santanach, P., 2004, The Alhama de Murcia fault (SE Spain), a seismogenic fault in a diffuse plate boundary-Seismotectonic implications for the Ibero-Magrebian region: Journal of Geophysical Research, v. 109, B01301, 17 p., doi.10.1029/2002JB002359.

Masana, E., Pallàs, R., Perea, H., Ortuño, M., Martínez-Díaz, J.J., García-Meléndez, E., and Santanach, P., 2005, Large Holocene morphogenic earthquakes along the Albox fault, Betic Cordillera, Spain: Journal of Geodynamics, v. 40, no. 2-3, p. 119-133.

Masana, E., Villamarín, J.A., Sánchez Cabañero, J., Plaza, J., and Santanach, P., 2001, Seismogenic faulting in an area of low seismic activity Paleoseismicity of the El Camp fault (Northeast Spain): Netherlands Journal of Geosciences, v. 80, no. 3-4, p. 229-241.

Masana, E., Villamarín, J.A., and Santanach, P., 2001, Paleoseismic results from multiple trenching analysis along a silent fault_ - The EI Camp fault (Tarragona, northeastern Iberian Peninsula): Acta Geologica Hispanica, v. 36, no. 3-4, p. 329-354.

Mason, D.P.M., and Little, T.A., 2006, Refined slip distribution and moment magnitude of the 1848 Marlborough earthquake, Awatere Fault, New Zealand: New Zealand Journal of Geology and Geophysics, v. 49, p. 375-382.

Matti, J.C., Tinsley, J.C., Morton, D.M., and McFadden, L.D., 1982, Holocene faulting history as recorded by alluvial stratigraphy within the Cucamonga fault zone-A preliminary view, Field Trip 12, in Tinsley, J.C., McFadden, L.D., and Matti, J.C., eds., Late Quaternary pedogenesis and alluvial chronologies of the Los Angeles and San Gabriel Mountain areas, southern California: Geological Society of America, Cordilleran Section, 78th Annual Meeting, Guidebook, Anaheim, Calif., p. 2144. 
McCalpin, J.P., 1982, Quaternary geology and neotectonics of the west flank of the northern Sangre de Cristo Mountains, south-central Colorado: Colorado School of Mines Quarterly, v. 77, no. 3, 97 p.

McCalpin, J.P., 1990, Latest Quaternary faulting in the northern Wasatch to Teton corridor (NWTC): Final Technical Report to U.S. Geological Survey under contract 14-08-001-G1395, 42 p.

McCalpin, J.P., 1993, Neotectonics of the northeastern Basin and Range margin, western USA: Zeitschrift fur Geomorphologie, Supplement Bd., v. 94, p. 137-157.

McCalpin, J.P., 1994, Neotectonic deformation along the East Cache fault zone, Cache County, Utah: Paleoseismology of Utah, v. 5 [Utah Geological Survey Special Study 83], 37 p.

McCalpin, J.P., 1997, Paleoseismicity of Quaternary faults near Albuquerque, New Mexico: Final Technical Report to U.S. Geological Survey under contract 1434-HQ-96-GR-02751, 18 p.

McCalpin, J.P., 2003, Neotectonics of the Bear Lake Valley, Utah and Idaho: Paleoseismology of Utah, v. 12 [Utah Geological Survey Miscellaneous Publication 03-4], 48 p.

McCalpin, J.P., 2006, Quaternary faulting and seismic source characterization in the El Paso-Juarez metropolitan area-Collaborative research with the University of Texas at El Paso: Final Technical Report to U.S. Geological Survey under contract 03HQGR0056, 68 p.

McCalpin, J.P., and Forman, S.L., 1991, Late Quaternary faulting and Thermoluminescence dating of the East Cache fault zone, north-central Utah: Bulletin of the Seismological Society of America, v. 81, no. 1, p. 139-161.

McCalpin, J.P., and Harrison, J.B.J., 2000, Paleoseismicity of Quaternary faults near Albuquerque, New Mexico: Final Technical Report to U.S. Geological Survey under contract 99HQGR0056, 46 p.

McCalpin, J.P., and Harrison, J.B.J., 2001, Paleoseismicity of Quaternary faults near Albuquerque, New Mexico: Final Technical Report to U.S. Geological Survey under contract 99HQGR0056, Second Year, $58 \mathrm{p}$.

McCrory, P.A., 1996, Evaluation of fault hazards, northern coastal California: U.S. Geological Survey Open-File Report 96-656, 87 p., http://pubs.er.usgs.gov/publication/ofr96656.

McCue, K., Van Dissen, R., Gibson, G., Jensen, V., and Boreham, B., 2003, The Lake Edgar Fault-An active fault in southwestern Tasmania, Australia, with repeated displacement in the Quaternary: Annals of Geophysics, v. 46, no. 5, p. 1,107-1,117.

McGill, S.F., and Sieh, K., 1991, Surficial offsets on the central and eastern Garlock fault associated with prehistoric earthquakes: Journal of Geophysical Research, v. 96, no. B13, p. 21,597-521,621.

Meghraoui, M., Philip, H., Albarede, F., and Cisternas, A., 1988, Trench investigations through the trace of the $1980 \mathrm{El}$ Asnam thrust fault-Evidence for paleoseismicity: Bulletin of the Seismological Society of America, v. 78, no. 2, p. 979-999.

Menges, C.M., Taylor, E.M., Wesling, J.R., Swan, F.H., Coe, J.A., Ponti, D.J., and Whitney, J.W., 2004, Summary of Quaternary Faulting on the Paintbrush Canyon, Bow Ridge, and Stagecoach Road Faults, chap. 5, in Keefer, W.R., Whitney, R.A., and Taylor, E.M., eds., Quaternary Paleoseismology and Stratigraphy of the Yucca Mountain Area, Nevada: U.S. Geological Survey Professional Paper 1689, p. 40-69, http://pubs.er.usgs.gov/publication/pp1689.

Michetti, A.M., Brunamonte, F., Serva, L., and Vittori, E., 1996, Trench investigations of the 1915 Fucino earthquake fault scarps (Abruzzo, central Italy) - Geological evidence of large historical events: Journal of Geophysical Research, v. 101, no. B3, p. 5,921-5,936.

Michetti, A.M., Brunamonte, F., Serva, L., and Whitney, R.A., 1995, Seismic hazard assessment from paleoseismological evidence in the Rieti region, central Italy, in Serva, L., and Slemmons, D.B., eds., Perspectives in Paleoseismology: Association of Engineering Geologists Special Publication No. 6, p. 19-33. 
Michetti, A.M., Ferreli, L., Serva, L., and Vittori, E., 1997, Geological evidence for strong historical earthquakes in an "aseismic" region-The Pollino case (southern Italy): Journal of Geodynamics, v. 24, no. 1-4, p. 67-86.

Mueller, K.J., and Rockwell, T.K., 1995, Late Quaternary activity of the Laguna Salada fault in northern Baja California, Mexico: Geological Society of America Bulletin, v. 107, no. 1, p. 8-18.

Myers, W.B., and Hamilton, W., 1964, Deformation accompanying the Hebgen Lake earthquake of August 17, 1959, The Hebgen Lake, Montana, earthquake of August 17, 1959: U.S. Geological Survey Professional Paper 435-I, p. 55-98.

Nazari, H., Ritz, J.-F., Balescu, S., Lamothe, M., Salamati, R., Talebian, M., Ghorashi, M., and Saidi, A., 2008, Paleoseismological analysis of the North Tehran Fault, Iran-Analyzing prehistoric ruptures for the past $30.000 \mathrm{ka}$ [abs.]: Oslo, Norway, 33rd International Geological Congress, Abstract 1189862.

Nazari, H., Ritz, J.F., Salamati, R., Shafei, A., Ghassemi, A., Michelot, J.L., Massault, M., and Ghorashi, M., 2009, Morphological and palaeoseismological analysis along the Taleghan fault (Central Alborz, Iran): Geophysical Journal International, v. 178, no. 2, p. 1,028-1,041.

Nelson, A.R., Johnson, S.Y., Kelsey, H.M., Wells, R.E., Sherrod, B.L., Pezzopane, S.K., Bradley, L.-A., Koehler, R.D., and Bucknam, R.C., 2003, Late Holocene earthquakes on the Toe Jam Hill fault, Seattle fault zone, Bainbridge Island, Washington: Geological Society of America Bulletin, v. 115, no. 11, p. 1,388-1,403.

Nelson, A.R., and Sullivan, J.T., 1992, Late Quaternary history of the James Peak fault, southernmost Cache Valley, north-central Utah, in Gori, P.L., and Hays, W.W., eds., Assessment of Regional Earthquake Hazards and Risk along the Wasatch Front, Utah: U.S. Geological Survey Professional Paper 1500-J, p. J1-J13.

Nelson, A.R., and VanArsdale, R.B., 1986, Recurrent late Quaternary movement on the Strawberry normal fault, Basin and Range-Colorado Plateau transition zone, Utah: Neotectonics, v. 1, p. 7-37.

Nicol, A., Walsh, J.J., Villamor, P., Seebeck, H., and Berryman, K.R., 2010, Normal fault interactions, paleoearthquakes and growth in an active rift: Journal of Structural Geology, v. 32, no. 8, p. 1,1011,113 .

Niemi, T.M., and Zhang, H., 2006, Determination of a high resolution paleoearthquake chronology for the northern San Andreas Fault at the Vedanta Marsh site, Marin County, CA: Final Technical Report to U.S. Geological Survey under contract 03HQGR0015, 11 p.

Nolan, J.M., Zinn, E.N., and Weber, G.E., 1995, Paleoseismic study of the southern Sargent fault, Santa Clara and San Benito Counties, California: Final Technical Report to U.S. Geological Survey under contract 1434-94-G-2466, 23 p.

Olig, S.S., Eppes, M.C., Forman, S.L., Love, D.W., and Allen, B.D., 2004, Paleoseismic investigation of the central Hubbell Spring Fault, central New Mexico: Final Technical Report to U.S. Geological Survey under contract 99HQGR0089, variously paginated.

Olig, S.S., Gorton, A.E., Black, B.D., and Forman, S.L., 2001, Paleoseismology of the Mercur Fault and segmentation of the Oquirrh-East Great Salt Lake fault zone, Utah: Final Technical Report to U.S. Geological Survey under contract 98HQGR1036, variously paginated.

Olig, S.S., Gorton, A.E., Bott, J.D., Wong, I.G., Knuepfer, P.L.K., Forman, S.L., Smith, R.P., and Simpson, D., 1995, Paleoseismic investigation of the southern Lost River fault zone, Idaho: Unpublished report prepared for Lockheed Idaho Technologies Company, Idaho National Engineering Laboratory, Idaho Falls, Idaho, under contract C93-134020, 81 p.

Olig, S.S., Lund, W.R., and Black, B.D., 1994, Large mid-Holocene and late Pleistocene earthquakes on the Oquirrh fault zone, Utah: Geomorphology, v. 10, p. 285-315. 
Olig, S.S., Lund, W.R., Black, B.D., and Mayes, B.H., 1996, Paleoseismic investigation of the Oquirrh fault zone, Tooele County, Utah-The Oquirrh fault zone, Tooele County, Utah-Surficial geology and paleoseismicity: Paleosesismology of Utah, v. 6 [Utah Geological and Mineral Survey Special Study 88], p. 22-64.

Ostenaa, D.A., Levish, D.R., and Klinger, R.E., 1995, Mission fault study: U.S. Bureau of Reclamation Seismotectonic Report 94-8, 111 p.

Ostenaa, D.A., Losh, S.L., and Nelson, A.R., 1981, Evidence for recurrent late Quaternary faulting, Sawatch fault, upper Arkansas Valley, Colorado, in Junge, W.R., ed., Colorado tectonics, seismicity, and earthquake hazards: Colorado Geological Survey Special Publication 19, p. 27-29.

Ota, Y., Beanland, S., Berryman, K.R., and Nairn, I.A., 1988, The Matata fault-Active faulting at the north-west margin of the Whakatane Graben, eastern Bay of Plenty: New Zealand Geological Survey Record 35, p. 6-13.

Ota, Y., Shishikura, M., Ichikawa, K., Watanabe, M., Yanagida, M., Tanaka, T., Sawa, H., Yamaguchi, M., Lee, Y.-H., Lu, S.-T., Shih, T.-S., and Amagasa, S., 2007, Low-angle reverse faulting during two earthquakes on the northern part of the Chelungpu fault, deduced from the Fengyuan trench, Central Taiwan: Terrestrial, Atmospheric and Oceanic Sciences, v. 18, no. 1, p. 55-66.

Ota, Y., Williams, D.N., and Berryman, K.R., 1981, Late Quaternary tectonic map of New Zealand, parts sheets Q27, R27 \& R28-Wellington (1st ed.): Wellington, New Zealand, Department of Scientific and Industrial Research, scale 1:50,000.

Padgett, D.C., and Rockwell, T.K., 1994, Paleoseismology of the Lenwood fault, San Bernardino, California, in Murbach, D., and Baldwin, J., eds., Mojave Desert: South Coast Geological Society Annual Field Trip Guidebook, no. 22, p. 222-238.

Palumbo, L., Benedetti, L., Bourles, D.L., Cinque, A., and Finkel, R., 2004, Slip history of the Magnola fault (Apennines, central Italy) from ${ }^{36} \mathrm{Cl}$ surface exposure dating-Evidence for strong earthquakes over the Holocene: Earth and Planetary Science Letters, v. 225, no. 1-2, p. 163-176.

Palyvos, N., Pavlopoulos, K., Froussou, E., Kranis, H., Pustovoytov, K., Forman, S.L., and MinosMinopoulos, D., 2010, Paleoseismological investigation of the oblique-normal Ekkara ground rupture zone accompanying the M 6.7-7.0 earthquake on 30 April 1954 in Thessaly, Greece-Archaeological and geochronological constraints on ground rupture recurrence: Journal of Geophysical Research, $\mathrm{v}$. 115, B06301, 25 p., doi.10.1029/2009JB006374.

Pantosti, D., Collier, R., D' Addezio, G., Masana, E., and Sakellariou, D., 1996, Direct geological evidence for prior earthquakes on the 1981 Corinth fault (central Greece): Geophysical Research Letters, v. 23, no. 25, p. 3,795-3,798.

Pantosti, D., D'Addezio, G., and Cinti, F.R., 1996, Paleoseismicity of the Ovindoli-Pezza fault, central Apennines, Italy - A history including a large, previously unrecorded earthquake in the Middle Ages (860-1300 A.D.): Journal of Geophysical Research, v. 101, no. B3, p. 5,937-5,959.

Pantosti, D., De Martini, P.M., Koukouvelas, I., Stamatopoulos, L., Palyvos, N., Pucci, S., Lemeille, F., and Pavlides, S., 2004a, Palaeoseismological investigations of the Aigion Fault (Gulf of Corinth, Greece): Comptes Rendus Geoscience, v. 336, no. 4-5, p. 335-342.

Pantosti, D., De Martini, P.M., Papanastassiou, D., Lemeille, F., Palyvos, N., and Stavrakakis, G., 2004b, Paleoseismological trenching across the Atalanti fault (central Greece)-Evidence for the ancestors of the 1894 earthquake during the Middle Ages and Roman times: Bulletin of the Seismological Society of America, v. 94, no. 2, p. 531-549.

Pantosti, D., Schwartz, D.P., and Valensise, G., 1993, Paleoseismology along the 1980 surface rupture of the Irpinia Fault-Implications for earthquake recurrence in the Southern Apennines, Italy: Journal of Geophysical Research, v. 98, no. B4, p. 6,561-6,577. 
Pearthree, P.A., and Calvo, S.S., 1987, The Santa Rita fault zone-Evidence for large magnitude earthquakes with very long recurrence intervals, Basin and Range province of southeastern Arizona: Bulletin of the Seismological Society of America, v. 77, no. 1, p. 97-116.

Peltzer, G., Tapponnier, P., Gaudemer, Y., Meyer, B., Guo, S., Yin, K., Chen, Z., and Dai, H., 1988, Offsets of late Quaternary morphology, rate of slip, and recurrence of large earthquakes on the Chang Ma Fault (Gansu, China): Journal of Geophysical Research, v. 93, no. 7, p. 7,793-7,812.

Personius, S.F., 1991, Paleoseismic analysis of the Wasatch fault zone at the Brigham City trench site, Brigham City, Utah and Pole Patch trench site, Pleasant View, Utah: Paleoseismology of Utah, v. 2 [Utah Geological and Mineral Survey Special Study 7], 39 p.

Personius, S.F., Crone, A.J., Machette, M.N., Mahan, S.A., Kyung, J.B., Cisneros, H., and Lidke, D.J., 2007, Late Quaternary paleoseismology of the southern Steens fault zone, northern Nevada: Bulletin of the Seismological Society of America, v. 97, no. 5, p. 1,662-1,678.

Personius, S.F., Crone, A.J., Machette, M.N., Mahan, S.A., and Lidke, D.J., 2009, Moderate rates of late Quaternary slip along the northwestern margin of the Basin and Range Province, Surprise Valley fault, northeastern California: Journal of Geophysical Research, v. 114, B09405, 17 p., doi.10.1029/2008jb006164.

Personius, S.F., and Mahan, S.A., 2000, Paleoearthquake recurrence on the East Paradise fault zone, metropolitan Albuquerque, New Mexico: Bulletin of the Seismological Society of America, v. 90, no. 2, p. 357-369.

Personius, S.F., and Mahan, S.A., 2003, Paleoearthquakes and eolian-dominated fault sedimentation along the Hubbell Spring fault zone near Albuquerque, New Mexico: Bulletin of the Seismological Society of America, v. 93, no. 3, p. 1,355-1,369.

Personius, S.F., and Mahan, S.A., 2005, Unusually low rates of slip on the Santa Rosa Range fault zone, northern Nevada: Bulletin of the Seismological Society of America, v. 95, no. 1, p. 319-333.

Pezzopane, S.K., Whitney, J.W., and Dawson, T.E., 1996, Models of earthquake recurrence and preliminary paleoearthquake magnitudes at Yucca Mountain, chap. 5, in Whitney, J.W., ed., Seismotectonic framework and characterization of faulting at Yucca Mountain, Nevada: Unpublished technical report prepared for U.S. Department of Energy, Denver, Colorado under contract DE-AC0494A185000, p. 5-1-5-100.

Philip, H., Avagyan, A., Karakhanian, A., Ritz, J.-F., and Rebai, S., 2001, Estimating slip rates and recurrence intervals for strong earthquakes along an intracontinental fault-Example of the PambakSevan-Sunik fault (Armenia): Tectonophysics, v. 343, no. 3-4, p. 205-232.

Philip, H., Rogozhin, E., Cisternas, A., Bousquet, J.C., Borisov, B., and Karakhanian, A., 1992, The Armenian earthquake of 1988 December 7-Faulting and folding, neotectonics and palaeoseismicity: Geophysical Journal International, v. 110, no. 1, p. 141-158.

Piety, L.A., and Anderson, L.W., 1990, Seismotectonic investigation for Horseshoe and Bartlett DamsSalt River Project, Arizona: U.S. Bureau of Reclamation Seismotectonic Report 90-7, 59 p.

Pondard, N., and Barnes, P.M., 2010, Structure and paleoearthquake records of active submarine faults, Cook Strait, New Zealand-Implications for fault interactions, stress loading, and seismic hazard:

Journal of Geophysical Research, v. 115, B12320, 31 p., doi.10.1029/2010jb007781.

Prentice, C.S., Kendrick, K.J., Berryman, K., Bayasgalan, A., Ritz, J.F., and Spencer, J.Q., 2002, Prehistoric ruptures of the Gurvan Bulag Fault, Gobi Altay, Mongolia: Journal of Geophysical Research, v. 107, no. B12, 2321, 18 p., doi.10.1029/2001jb000803.

Qian, H., Luo, Z., and Wen, X., 1991, Preliminary study of characteristic earthquakes of the Xianshuihe fault zone: Acta Seismologica Sinica, v. 4, no. 1, p. 29-42. 
Qian, H., Luo, Z., and Wen, X., 1992, The characteristic earthquakes along the Xianshuihe fault and estimation of earthquake trend, in Proceedings of the PRC-US Bilateral Symposium on the Xianshuihe fault zone: Chengdu, China, Seismological Press, p. 33-40.

Ragona, D., Rockwell, T.K., and Altangerel, O., 2003, Earthquake behavior across a fault segment boundary - A high resolution paleoseismic study in the southern San Jacinto fault zone, Imperial Valley, southern California [abs.]: Geological Society of America Abstracts with Programs, v. 35, no. 4, p. 27.

Ramelli, A.R., Bell, J.W., dePolo, C.M., and Yount, J.C., 1999, Large-magnitude, late Holocene earthquakes on the Genoa fault, west-central Nevada and eastern California: Bulletin of the Seismological Society of America, v. 89, no. 6, p. 1,458-1,472.

Ramelli, A.R., dePolo, C.M., and Bell, J.W., 1994, Synthesis of data and exploratory trenching along the northern Sierra Nevada fault zone: Final Technical Report to U.S. Geological Survey under contract 1434-95-G-2606, 65 p.

Ramelli, A.R., dePolo, C.M., and Bell, J.W., 1999, Paleoseismic studies of the northern Sierra Nevada Range-front fault system: Final Technical Report to U.S. Geological Survey under contract 1434-HQ97-Gr-03043, 16 p.

Ramelli, A.R., dePolo, C.M., and Bell, J.W., 2000, Paleoseismic studies of the Peavine Peak fault: Final Technical Report to U.S. Geological Survey under contract 01HQGR0167, 15 p.

Ramelli, A.R., Oswald, J.A., Vadurro, G., Menges, C.M., and Price, J.B., 2004, Quaternary Faulting on the Solitario Canyon Fault, chap. 7, in Keefer, W.R., Whitney, R.A., and Taylor, E.M., eds., Quaternary Paleoseismology and Stratigraphy of the Yucca Mountain Area, Nevada: U.S. Geological Survey Professional Paper 1689, p. 89-109, http://pubs.usgs.gov/pp/pp1689/.

Ran, Y., Chen, L., Cheng, J., and Gong, H., 2008, Late Quaternary surface deformation and rupture behavior of strong earthquake on the segment north of Mianning of the Anninghe Fault-Science in China Series D: Earth Sciences, v. 51, no. 9, p. 1,224-1,237.

Ran, Y., Deng, Q., Yang, X., Zhang, W., Li, R., and Xiang, H., 1997, Paleoearthquakes and recurrence interval on the seismogenic fault of 1679 Sanhe-Pinggu M 8 earthquake, Hebei and Beijing: Seismology and Geology, v. 19, no. 3, p. 193-201 [in Chinese, English summary].

Ran, Y., Duan, R., Deng, Q., Jiao, D., and Min, W., 1997, 3-D trench excavation and paleoseismology at Gaowanzi of the Haiyuan Fault: Seismology and Geology, v. 19, no. 2, p. 97-107 [in Chinese, English summary].

Ran, Y., Fang, Z., Duan, R., Li, Z., Wang, J., Z., Y., Ji, F., and Li, J., 1996, Model for paleoearthquake recurrence along Baying segment of the north margin fault of Fanshan Basin in Hebei Province:

Earthquake Research in China, v. 10, no. 1, p. 87-100.

Ran, Y., Wang, J., Peng, S., and Deng, Q., 1995, Paleoearthquake traces along the southern boundary fault of Xuanhua basin, Hebei Provence: Seismology and Geology, v. 17, no. 1, p. 44-46 [in Chinese, English summary].

Reicherter, K.R., 2001, Paleoseismologic advances in the Granada basin (Betic Cordilleras, southern Spain): Acta Geologica Hispanica, v. 36, no. 3-4, p. 267-281.

Research Group for the Senya fault, 1986, Holocene activities and near-surface features of the Senya fault, Akita Prefecture, Japan-Excavation study at Komori, Senhata-cho: Bulletin of the Earthquake Research Institute, University of Tokyo, v. 61, part 2, p. 339-402 [in Japanese with English summary]. 
Rockwell, T., 1989, Behavior of individual fault segments along the Elsinore-Laguna Salada fault zone, southern California and northern Baja California: implications for the characteristic earthquake model, in Schwartz, D., and Sibson, R.H., eds., Fault Segmentation and Controls of Rupture Initiation and Termination, Proceedings of Workshop XLV: U.S. Geological Survey Open-File Report 89-315, p. 288-308.

Rockwell, T., Fonseca, J., Madden, C., Dawson, T., Owen, L.A., Vilanova, S., and Figueiredo, P., 2009, Palaeoseismology of the Vilariça segment of the Manteigas-Bragança fault in northeastern Portugal, in Reicherter, K.R., Michetti, A.M., and Silva, P.G., eds., Palaeosismology-Historical and Prehistorical Records of Earthquake Ground Effects for Seismic Hazard Assessment: The Geological Society, London, Special Publications, v. 316, p. 237-258.

Rockwell, T.K., Gath, E., Gonzalez, T., Madden, C., Verdugo, D., Lippincott, C., Dawson, T.E., Owen, L.A., Fuchs, M., Cadena, A., Williams, P., Weldon, E., and Franceschi, P., 2010, Neotectonics and paleoseismology of the Limon and Pedro Miguel faults in Panama-Earthquake hazard to the Panama Canal: Bulletin of the Seismological Society of America, v. 100, no. 6, p. 3,097-3,129.

Rockwell, T.K., Lindvall, S., Herzberg, M., Murbach, D., Dawson, T., and Berger, G., 2000, Paleoseismology of the Johnson Valley, Kickapoo, and Homestead Valley faults - Clustering of earthquakes in the eastern California shear zone: Bulletin of the Seismological Society of America, v. 90, no. 5, p. 1,200-1,236.

Rockwell, T.K., and Meltzner, A.J., 2008, Non-characteristic slip and earthquake clustering on the Imperial fault, Mesquite Basin, Imperial Valley, California [abs.], Abstract T11A-1845: Eos, Transactions American Geophysical Union, v. 89, no. 53, Supplement.

Rockwell, T.K., and Pinault, C.T., 1986, Holocene slip events on the southern Elsinore fault, Coyote Mountains, southern California, in Ehlig, P.L., ed., Neotectonics and faulting in southern California: Los Angeles, Calif., Geological Society of America, Cordilleran Section, 82nd Annual Meeting, Guidebook, p. 193-196.

Rodgers, D.W., and Little, T.A., 2006, World's largest coseismic strike-slip offset-The 1855 rupture of the Wairarapa Fault, New Zealand, and implications for displacement/length scaling of continental earthquakes: Journal of Geophysical Research, v. 111, B12408, 19 p., doi:10.1029/2005JB004065.

Rogozhin, E.A., and Ovsyuchenko, A.N., 2005, Seismic and geologic activity of tectonically faulted structures in the Northern Caucasus: Physics of the Solid Earth, v. 41, no. 6, p. 449-461.

Rogozhin, E.A., Ovsyuchenko, A.N., Marakhanov, A.V., and Ushanova, E.A., 2007, Tectonic setting and geological manifestations of the 2003 Altai earthquake: Geotectonics, v. 41, no. 2, p. 87-104.

Rogozhin, E.A., Ovsyuchenko, A.N., and Parvez, I.A., 2010, Paleoseismogeological investigations in a "seismic gap" in the Northwest Caucasus compared to the West Himalayan region: Seismic Instruments, v. 46, no. 4, p. 356-362.

Rubin, C.M., Lindvall, S.C., and Rockwell, T.K., 1998, Evidence for large earthquakes in metropolitan Los Angeles: Science, v. 281, p. 398-402.

Rubin, C.M., and Sieh, K., 1997, Long dormancy, low slip rate, and similar slip-per-event for the Emerson fault, eastern California shear zone: Journal of Geophysical Research, v. 102, no. B7, p. 15,319-15,333.

Rubin, C.M., Thompson, S., Abdrakhmatov, K., and Weldon, R., 1999, Thrust fault paleoseismology in an intercontinental tectonic setting, Kyrgyz Tien Shan, central Asia [abs.]: Geological Society of America Abstracts with Programs, p. A-376.

Salomon, E., Schmidt, S., Hetzel, R., and Mingorance, F., 2010, Paleoseismic investigations at the Cal thrust fault, Mendoza, Argentina [abs.]: Geophysical Research Abstracts, v. 12, EGU2010-4881. 
Salvi, S., Cinti, F.R., Colini, L., D'Addezio, G., Doumaz, F., and Pettinelli, E., 2003, Investigation of the active Celano-L'Aquila fault system, Abruzzi (Central Apennines, Italy) with combined groundpenetrating radar and palaeoseismic trenching: Geophysical Journal International, v. 155, no. 3, p. 805-818.

Sarna-Wojcicki, A.M., Lajoie, K.R., and Yerkes, R.F., 1987, Recurrent Holocene displacement on the Javon Canyon fault-A comparison of fault-movement history with calculated average recurrence intervals, in Morton, D.M., and Yerkes, R.F., eds., Recent reverse faulting in the Transverse Ranges, California: U.S. Geological Survey Professional Paper 1339, p. 125-135.

Sawyer, T.L., 1988, Late Holocene paleoseismicity of the northern Death Valley fault system, Fish Lake Valley, Nevada, in Ellis, M.A., ed., Late Cenozoic Evolution of the Southern Great Basin: Nevada Bureau of Mines and Geology Open-File Report 89-1, p. 63-78.

Sawyer, T.L., 1990, Quaternary geology and neotectonic activity along the Fish Lake Valley fault zone, Nevada and California: Reno, University of Nevada, Master's thesis, 379 p.

Schell, B.A., and Euge, K.M., 1992, Neotectonics and seismic hazards of the Aubrey fault, northwestern Arizona, in Stout, M.L., ed., Proceedings of the 35th Annual Meeting of the Association of Engineering Geologists: Los Angeles, Calif., Association of Engineering Geologists, p. 214-223.

Schell, B.A., and Schell, W.A., 1994, Blue Cut fault, Riverside County, southern California, in Murbach, D., and Baldwin, J., eds., Mojave Desert: South Coast Geological Society Annual Field Trip Guidebook, no. 22, p. 208-221.

Schermer, E.R., Van Dissen, R., Berryman, K.R., Kelsey, H.M., and Cashman, S.M., 2004, Active faults, paleoseismology, and historical fault rupture in northern Wairarapa, North Island, New Zealand: New Zealand Journal of Geology and Geophysics, v. 47, no. 1, p. 101-122.

Schlagenhauf, A., Gaudemer, Y., Benedetti, L., Manighetti, I., Palumbo, L., Schimmelpfennig, I., Finkel, R., and Pou, K., 2010, Using in situ chlorine-36 cosmonuclide to recover past earthquake histories on limestone normal fault scarps: a reappraisal of methodology and interpretations:

Geophysical Journal International, v. 182, no. 1, p. 36-72.

Schlom, T.M., and Knott, J.R., 2010, Earthquake magnitude and recurrence from scarp morphology, Eureka Valley fault zone, eastern California [abs.]: Geological Society of America Abstracts with Programs, v. 42, no. 4, p. 64.

Schwartz, D.P., 1988, Paleoseismicity and neotectonics of the Cordillera Blanca fault zone, northern Peruvian Andes: Journal of Geophysical Research, v. 93, no. B5, p. 4,712-4,730.

Schwartz, D.P., and Coppersmith, K.J., 1984, Fault behavior and characteristic earthquakes-Examples from the Wasatch and San Andreas fault zones: Journal of Geophysical Research, v. 89, no. B7, p. $5,681-5,698$.

Schwartz, D.P., and Crone, A.J., 1985, The 1983 Borah Peak earthquake-A calibration event for quantifying earthquake recurrence and fault behavior on Great Basin normal faults, in Stein, R.S., and Bucknam, R.C., eds., Proceedings of Workshop XXVIII on the Borah Peak, Idaho EarthquakeVolume A: U.S. Geological Survey Open-File Report 85-290, p. 153-160, http://pubs.er.usgs.gov/publication/ofr85290A.

Schwartz, D.P., Hecker, S., Ponti, D.J., Bayasgalan, A., Lund, W.R., Stenner, H.D., and Enkbaatar, D., 1999, Paleoseismic reconnaissance along the great 1905 Bulnay, Mongolia surface rupture [abs.]: Seismological Research Letters, v. 70, no. 2, p. 235.

Seitz, G., Weldon, R.J., II, and Biasi, G.P., 1997, The Pitman Canyon paleoseismic record-A reevaluation of southern San Andreas fault segmentation: Journal of Geodynamics, v. 24, no. 1-4, p. 129-138. 
Seitz, G.G., Biasi, G.P., and Weldon, R.J., II, 2000, An improved paleoseismic record of the San Andreas fault at Pitman Canyon, in Noller, J.S., Sowers, J.M., and Lettis, W.R., eds., Quaternary Geochronology-Methods and Applications: American Geophysical Union Reference Shelf, v. 4, p. 563-5663, doi: 10.1029/RF004.

Shi, Y., Li, J., Feng, X., Dai, W., Ren, J., Li, X., and Dou, M., 2007, The study of paleoearthquakes on the Weihe Fault Zone: Seismology and Geology, v. 29, no. 3, p. 607-616 [in Chinese, English summary].

Shishikura, M., Toda, S., Kariya, Y., Nagai, S., Nikaido, M., and Takase, N., 2002, Paleoseismological study of the Kiso-sanmyaku-seien fault zone (2) - Geological and geomorphological survey at Fukutochizawa site across the Magome-toge fault: Annual Report on Active Fault and

Paleoearthquake Researches, no. 2, p. 57-68 [In Japanese, English summary].

Sieh, K.E., 1984, Lateral offsets and revised dates of large prehistoric earthquakes at Pallett Creek, Southern California: Journal of Geophysical Research, v. 89, no. B9, p. 7,641-7,670.

Silva, P.G., Goy, J.L., Zazo, C., Lario, J., and Bardaji, T., 1997, Paleoseismic indications along "aseismic" fault segments in the Guadalentin Depression (SE Spain): Journal of Geodynamics, v. 24, no. 1-4, p. 105-115.

Simpson, G.D., Thompson, S.C., Noller, J.S., and Lettis, W.R., 1997, The northern San Gregorio fault zone-Evidence for the timing of late Holocene earthquakes near Seal Cove, California: Bulletin of the Seismological Society of America, v. 87, no. 5, p. 1,158-1,170.

Sowers, J.M., Unruh, J.R., Lettis, W.R., and Rubin, T.D., 1994, Relationship of the Kickapoo Fault to the Johnson Valley and Homestead Valley faults, San Bernardino County, California: Bulletin of the Seismological Society of America, v. 84, no. 3, p. 528-536.

Sugai, T., Awata, Y., and Shimokawa, K., 1998, Paleoseismological study of the Kuwana fault and the Yokkaichi fault in Mie Prefecture, central Japan: Geological Survey of Japan Interim Report, no. EQ/98/1, p. 75-90 [in Japanese with English summary].

Sugai, T., Emre, O., Duman, T.Y., Yoshioka, T., and Kuscu, I., 1998, Geologic evidence for five large earthquakes on the North Anatolian fault at Ilgaz, during the last two millennia [abs.]: Eos, Transactions American Geophysical Union, v. 79, no. 45, p. F615.

Sugai, T., Emre, O., Duman, T.Y., Yoshioka, T., and Kuscu, I., 1999, Geologic evidence for five large earthquakes on the North Anatolian fault at Ilgaz, during the last 2000 years - A result of GSJ-MTA international cooperative research, in Proceedings of the Paleoseismology Workshop, March 15, 1999, Tsukuba, Japan: GSJ Interim Report No. EQ/99/2 and U.S. Geological Survey Open-File Report 99-400, p. 66-72.

Sullivan, J.T., and Nelson, A.R., 1992, Late Quaternary displacement on the Morgan fault, a back valley fault in the Wasatch Range of northeastern Utah, in Gori, P.L., and Hays, W.W., eds., Assessment of Regional Earthquake Hazards and Risk along the Wasatch Front, Utah: U.S. Geological Survey Professional Paper 1500-I, p. I1-I19.

Sutherland, R., and Norris, R.J., 1995, Late Quaternary displacement rate, paleoseismicity, and geomorphic evolution of the Alpine fault_Evidence from Hokuri Creek, South Westland, New Zealand: New Zealand Journal of Geology and Geophysics, v. 38, no. 4, p. 419-430.

Tapponnier, P., Ryerson, F.J., Van der Woerd, J., Meriaux, A.-S., and Lasserre, C., 2001, Long-term slip rates and characteristic slip-Keys to active fault behavior and earthquake hazard: Earth and Planetary Science, v. 333, no. 9, p. 483-494. 
Taylor, E.M., 2004, Quaternary faulting on the Southern Crater Flat Fault, in Keefer, W.R., Whitney, R.A., and Taylor, E.M., eds., Quaternary Paleoseismology and Stratigraphy of the Yucca Mountain Area, Nevada: U.S. Geological Survey Professional Paper 1689, p. 135-144, http://pubs.usgs.gov/pp/pp1689/.

Toda, S., Miura, D., Abe, S., Miyakoshi, K., and Inoue, D., 1999, Recent surface-faulting events along the southern part of the Itoigawa-Shizuoka Tectonic Line, central Japan, in Proceedings of the Paleoseismology Workshop, March 15, 1999, Tsukuba, Japan: GSJ Interim Report No. EQ/99/2 and U.S. Geological Survey Open-File Report 99-400, p. 92-96.

Toda, S., Miura, D., Miyakoshi, K., and Inoue, D., 2000, Recent surface faulting events along the southern part of the Itoigawa-Shizuoka Tectonic Line: Journal of the Seismological Society of Japan, v. 52, no. 445-468 [in Japanese with English summary].

Townsend, D., Nicol, A., Mouslopoulou, V., Begg, J.G., Beetham, R.D., Clark, D., Giba, M., Heron, D., Lukovic, B., McPherson, A., Seebeck, H., and Walsh, J.J., 2010, Palaeoearthquake histories across a normal fault system in the southwest Taranaki Peninsula, New Zealand: New Zealand Journal of Geology and Geophysics, v. 53, no. 4, p. 375-394.

Townsend, T., 1998, Paleoseismology of the Waverely Fault Zone and implications for earthquake hazard in South Taranaki, New Zealand: New Zealand Journal of Geology and Geophysics, v. 41, p. 467-474.

Tsutsumi, H., and Okada, A., 1996, Segmentation and Holocene surface faulting on the Median Tectonic Line, southwest Japan: Journal of Geophysical Research, v. 101, no. B3, p. 5,855-5,871. van den Berg, M., Vanneste, K., Dost, B., Lokhorst, A., van Eijk, M., and Verbeeck, K., 2002, Paleoseismic investigations along the Peel Boundary Fault - Geological setting, site selection and trenching results: Netherlands Journal of Geosciences, v. 81, no. 1, p. 39-60.

van der Woerd, J., Tapponnier, P., Ryerson, F.J., Meriaux, A.-S., Meyer, B., Gaudemer, Y., Finkel, R.C., Caffee, M.W., Zhao, G., and Xu, Z., 2002, Uniform postglacial slip-rate along the central 600 $\mathrm{km}$ of the Kunlun Fault (Tibet), from ${ }^{26} \mathrm{Al},{ }^{10} \mathrm{Be},{ }^{14} \mathrm{C}$ dating of riser offsets, and climatic origin of the regional morphology: Geophysical Journal International, v. 148, no. 3, p. 356-388.

Vandenberghe, D., Vanneste, K., Verbeeck, K., Paulissen, E., Buylaert, J.-P., De Corte, F., and Van den haute, P., 2009, Late Weichselian and Holocene earthquake events along the Geleen fault in NE Belgium-OSL age constraints: Quaternary International, v. 199, no. 1-2, p. 56-74.

Vanneste, K., Radulov, A., De Martini, P., Nikolov, G., Petermans, T., Verbeeck, K., Camelbeeck, T., Pantosti, D., Dimitrov, D., and Shanov, S., 2006, Paleoseismologic investigation of the fault rupture of the 14 April 1928 Chirpan earthquake (M 6.8), southern Bulgaria: Journal of Geophysical Research, v. 111, B01303, 16 p., doi.10.1029/2005JB003814.

Vanneste, K., Verbeeck, K., Camelbeeck, T., Paulissen, E., Meghraoui, M., Renardy, F., Jongmans, D., and Frechen, M., 2001, Surface-rupturing history of the Bree fault scarp, Roer Valley grabenEvidence for six events since the late Pleistocene: Journal of Seismology, v. 5, p. 329-359.

Verdugo, D.M., Ragona, D., and Rockwell, T.K., 2007, Slip in the past 5 earthquakes on the Superstition Mountain fault at Carrizo Wash, southern San Jacinto fault zone, southern California [abs.]: Seismological Research Letters, v. 78, no. 2, p. 316.

Villamor, P., Van Dissen, R., Alloway, B.V., Palmer, A.S., and Litchfield, N., 2007, The Rangipo fault, Taupo rift, New Zealand-An example of temporal slip-rate and single-event displacement variability in a volcanic environment: Bulletin of the Geological Society of America, v. 119, no. 5, p. 529-547. 
Vincent, K.R., 1985, Measurement of vertical tectonic offset using longitudinal profiles of faulted geomorphic surfaces near Borah Peak, Idaho-A preliminary report, in Stein, R.S., and Bucknam, R.C., eds., Proceedings of Workshop XXVIII on the Borah Peak, Idaho Earthquake: U.S. Geological Survey Open-File Report 85-290, p. 76-96.

Vincent, K.R., 1995, Implications for models of fault behavior from earthquake surface-displacement along adjacent segments of the Lost River fault, Idaho: Tucson, Ariz., University of Arizona, Ph.D. dissertation, $152 \mathrm{p}$.

Wallace, R.E., 1980, Degradation of the Hebgen Lake fault scarps of 1959: Geology, v. 8, p. 225-229.

Wang, H., 1996, Holocene slip rate, paleoearthquakes, and recurrence interval of strong earthquakes on the fault where the 1688 Tancheng $\mathrm{M}=8.5$ earthquake occurred, Shandong Province: Journal of Seismological Research, v. 19, no. 2, p. 206-224.

Wang, H., Hou, Z., Guo, J., Chen, A., and Hou, K., 1994, The Changma fault zone, Gansu Province, China, and its recent activity: Journal of Seismological Research, v. 17, no. 1, p. 79-107.

Watanabe, M., Ikeda, Y., Suzuki, Y., and Sugai, T., 1994, Paleoseismicity and fault structure of the western boundary active faults of the Kitakami Lowland, northeast Japan-Excavation study of the Uwandaira fault group, west of Hanamaki City: Geographical Review of Japan, v. 67 (Ser. A), no. 6, p. 393-403 [in Japanese with English summary].

Weldon, R.J., II, Biasi, G.P., Wills, C.J., and Dawson, T., 2008, Overview of the southern San Andreas fault model, Appendix E- The Uniform California Earthquake Rupture Forecast, version 2 (UCERF 2): U.S. Geological Survey Open-File Report 2007-1437E and California Geological Survey Special Report 203-E.

Wesnousky, S.G., Barron, A.D., Briggs, R.W., Caskey, S.J., Kumar, S., and Owen, L., 2005, Paleoseismic transect across the northern Great Basin: Journal of Geophysical Research, v. 110, B05408, 25 p., doi.10.1029/2004JB003283.

West, M.W., 1994, Seismotectonics of north-central Utah and southwestern Wyoming: Paleoseismology of Utah, v. 4 [Utah Geological Survey Special Study 82], 93 p.

Whitney, J.W., Simonds, F.W., Shroba, R.R., and Murray, M., 2004, Quaternary faulting on the Windy Wash Fault, in Keefer, W.R., Whitney, R.A., and Taylor, E.M., eds., Quaternary Paleoseismology and Stratigraphy of the Yucca Mountain Area, Nevada: U.S. Geological Survey Professional Paper 1689, p. 125-134, http://pubs.usgs.gov/pp/pp1689/.

Williams, D.N., 1975, Ohariu fault zone at Porirua, Wellington, New Zealand: New Zealand Journal of Geology and Geophysics, v. 18, no. 5, p. 659-665.

Williams, P.L., 1989, Aspects of the earthquake geology and seismotectonics of the southern San Andreas and related faults, southern California: New York, Columbia University, Ph.D. dissertation.

Witter, R.C., Givler, R.W., and Carson, R.J., 2008, Two post-glacial earthquakes on the Saddle Mountain West fault, southeastern Olympic Peninsula, Washington: Bulletin of the Seismological Society of America, v. 98, no. 6, p. 2,894-2,917.

Xie, X., Zhao, J., Jiang, W., An, W., Li, Z., Zhang, D., Cheng, X., Gao, S., Wang, C., Sun, C., and Yan, C., 2007, Study on Holocene paleoearthquakes in Xizhang trench on the Jiaocheng fault zone, Shanxi Province: Seismology and Geology, v. 29, no. 4, p. 744-755 [In Chinese, English summary].

Yaneva, M., Radulov, A., Nikolov, G., Shanov, S., Kamelbeeck, T., Nikolov, N., Mitev, A., Kostov, K., Vanneste, K., Verbeeck, K., and Kovachev, V., 2004, Geological records for paleoseismisity of Popovitsa Fault in a trench near Popovitsa, southern Bulgaria, in Annual Scientific Conference Geology 2004, Sofia, Bulgaria, 2004, Proceedings: Sofia, Bulgaria, Bulgarian Geological Survey, p. 107-109. 
Yang, X., Ran, Y., Hu, B., and Guo, W., 2003, Paleoseismic activity on Wujiahe segment of Serteng Piedmont Fault, Inner Mongolia: Acta Seismologica Sinica (English Version), v. 16, no. 1, p. 67-78. Yen, I.C., Chen, W.-S., Yang, C.-C.B., Huang, N.-W., and Lin, C.-W., 2008, Paleoseismology of the Rueisuei segment of the Longitudinal Valley fault, eastern Taiwan: Bulletin of the Seismological Society of America, v. 98, no. 4, p. 1,737-1,749.

Zhang, P., Ellis, M.A., Slemmons, D.B., and Mao, F., 1990, Right-lateral displacements and the Holocene slip rate associated with prehistoric earthquakes along the southern Panamint Valley fault zone-Implications for southern Basin and Range tectonics and coastal California deformation: Journal of Geophysical Research, v. 95, no. 4, p. 4,857-4,872.

Zollweg, J.E., Waag, C.J., and Beukelman, G.S., 1998, Possible Holocene faulting on the margin of the western Snake River Plain, Idaho: Final technical report to U.S. Geological Survey under contract 1434-HQ-97-GR-03005, 25 p. 